\title{
Audit Tata Kelola Teknologi Informasi pada Dinas Pariwisata Kabupaten X Menggunakan Framework COBIT 5
}

\author{
I Gede Billy Aditya Agansa ${ }^{[1]}$, Gusti Agung Ayu Putri ${ }^{[2]}$, Anak Agung Ngurah Hary Susila ${ }^{[3]}$ \\ Program Studi Teknologi Informasi \\ Fakultas Teknik, Universitas Udayana \\ Jl. Raya Kampus Unud Jimbaran, Kec. Kuta Selatan, Kabupaten Badung, Bali \\ $\underline{\text { adityaagansa8@gmail.com }}^{[1]}$, agung.ayuputri@unud.ac.id ${ }^{[2]}, \underline{\text { harysusila@ } @ \text { unud.ac.id }}^{[3]}$
}

\begin{abstract}
The development of Information Technology has a great influence on all aspects of people's lives, especially in a government agency. Dinas Pariwisata Kabupaten $\mathrm{X}$ utilizes information technology with the aim of increasing the ability to process, manage, distribute, and distribute information and public services as well as improve government performance in transparency and accountability towards good governance. Therefore, it is necessary to conduct an audit aimed at evaluating the current information governance. In this study, the capability model is used as a measuring tool for respondents' answers to the questionnaire based on the COBIT 5 framework. The number of respondents involved in filling out the questionnaire was taken as many as 21 people, namely from the top and middle level management. Based on the recapitulation of answers from the respondents, the results obtained from this audit show that the capability level of the five IT processes is at a low value, namely DSS02 is at level 1, APO06 is at level 1, EDM02 is at level 1, BAI04 is at level 1 , and APO04 at level 1. In order to get the expected results, several recommendations are made to improve performance as well as a reference for improving employee performance at Dinas Pariwisata Kabupaten X.
\end{abstract}

Keywords-Audit, IT Governance, Information Technology, COBIT 5

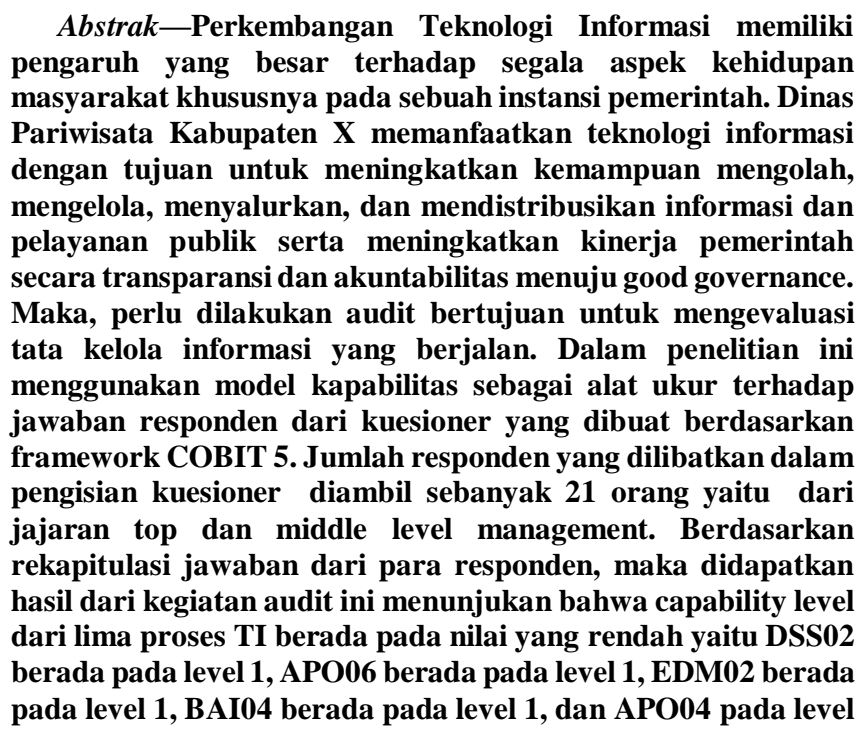

1. Untuk mendapatkan hasil yang diharapkan, maka dibuatlah beberapa rekomendasi untuk meningkatkan kinerja serta acuan perbaikan kinerja pegawai di Dinas Pariwisata Kabupaten X.

Kata kunci-Audit, Tata Kelola TI, Teknologi Informasi, COBIT 5.

\section{INTRODUCTION}

Perkembangan teknologi informasi menuntut perusahaan untuk melakukan pengembangan internal maupun eksternal organisasi. Hal ini mengakibatkan teknologi informasi telah menjadi bagian penting dalam mendukung setiap proses bisnis dan pertumbuhan perusahaan maupun instansi pemerintah. Teknologi informasi juga memainkan peran penting dalam organisasi. Selama bertahun-tahun, Teknologi Informasi telah beralih bukan hanya sebagai support melainkan sebagai suatu keharusan di organisasi.

Perkembangan TI (teknologi informasi) saat ini sangat penting bagi organisasi karena kehadiran TI (teknologi informasi) membantu meningkatkan efektivitas dan efisiensi proses bisnis perusahaan[1]. Tata kelola TI (teknologi informasi) adalah kebijakan atau struktur prosedural dan serangkaian proses organisasi yang dirancang untuk mengoptimalkan manfaat dan peluang yang diberikan oleh TI (teknologi informasi), mengontrol penggunaan sumber daya TI (teknologi informasi), dan mengelola risiko terkait TI (teknologi informasi)[2].Teknologi yang telah ada haruslah dikontrol atau dilakukan pengecekan terhadap tata kelola TI yang baik. 3 manfaat utama yang akan didapat ketika perusahaan telah menerapkan tata kelola TI yang baik yaitu benefit realization (realisasi Manfaat), Risk Optimization (Optimalisasi Risiko) dan Resource Optimalization (Optimalisasi sumber daya)[3].

Dinas Pariwisata Kabupaten X merupakan unsur pelaksana Otonomi Daerah yang bertanggungjawab terhadap segala hal terkait pariwisata baik dalam merumuskan kebijakan, mengadakan pembinaan dan pengawasan serta memberikan pelayanan umum di Bidang Pariwisata Kabupaten X. Dinas Pariwisata Kabupaten X memanfaatkan teknologi informasi dengan tujuan untuk meningkatkan kemampuan mengolah, mengelola, menyalurkan, dan mendistribusikan informasi dan pelayanan publik serta 
meningkatkan kinerja pemerintah secara transparansi dan akuntabilitas menuju good governance. Tata kelola yang baik merupakan suatu upaya untuk mewujudkan visi dan misi dalam organisasi serta memperpendek lini pengambilan keputusan dan meningkatkan kualitas, Dinas Pariwisata belum mengetahui tingkat kematangan Tata kelola TI saat ini (current capability). Sehingga untuk mewujudkan Dinas Pariwisata menuju good governance dengan tata kelola yang baik perlu diadakan audit dengan evaluasi yang mencangkup tujuan dari organisasi. Audit tata kelola TI bertujuan untuk mengetahui tingkat kematangan tata kelola TI pada Dinas Pariwisata dan memberikan rekomendasi untuk meningkatkan capability level. Penerapan audit dengan mengangkat indikator kerja dari RENSTRA menggunakan framework COBIT 5 digunakan sebagai tolak ukur pencapaian dinas sesuai dengan tujuan dan visi misi yang diharapkan. Audit tata kelola TI (teknologi informasi) pada Dinas Pariwisata Kabupaten $\mathrm{X}$ dilakukan menggunakan COBIT 5 karena COBIT 5 menyediakan analisis untuk membantu organisasi atau perusahaan dalam meningkatkan pencapaian tujuan dan aspek manajemen tata kelola TI (teknologi informasi).

\section{LANDASAN TEORI}

Audit tata kelola teknologi informasi sudah pernah dilakukan sebelumnya, seperti penelitian mengenai audit tata kelola Training Center menggunakan framework COBIT 5. Penelitian ini bertujuan untuk mendapatkan gambaran tentang kinerja tata kelola teknologi informasi dalam menentukan sejauh mana kapabilitas tata kelola teknologi informasi yang ada saat ini. Tata kelola teknologi informasi yang digunakan berfokus pada domain DSS (deliver, service, dan support) untuk meningkatkan efektivitas, efisiensi dan unit fungsional teknologi informasi dalam sebuah organisasi[4].

Penelitian terkait yang dilakukan Heru Nugroho dengan judul "Proposed IT Governance at Hospital Based on COBIT 5 Framework" [5] membahas tentang tata kelola TI pada rumah sakit. Penelitian ini mengikuti Metodologi Penelitian DSRM (Design Science Research Methodology) yang bertujuan untuk memberikan peningkatan kualitas, fungsionalitas, dan kemudahan penggunaan layanan. Beberapa model referensi proses pada COBIT 5 yang relevan dan dapat digunakan dalam menerapkan tata kelola ti di rumah sakit yaitu APO01, APO02, APO03, APO06, APO07, APO09, BAI02, BAI03, BAI09, DSS01, DSS02, DSS03, DSS06, MEA01 dan MEA02.

Penelitian yang berjudul "Internal Control Improvement for Creating Good Governance"[6] melakukan penelitian pada koperasi dengan tata kelola yang masih kurang atau belum optimal ke beberapa koperasi yang ada di Denpasar. Penelitian dimulai dengan melakukan survei terhadap koperasi dalam wawancara, melihat log sistem dan kuesioner. Hasil dari survei tersebut lalu dirumuskan menjadi titik kritis yang kemudian digunakan sebagai dasar dari pemetaan menggunakan kerangka COBIT 5. Titik kritis kemudian dipilih sesuai dengan levelnya lalu dipetakan ke proses bisnis atau SOP koperasi.
Penelitian lainya yaitu penelitian mengenai audit implementasi tata kelola teknologi informasi menggunakan framework COBIT 5 di BPMPTSP Bone Bolango[7]. Penelitian ini melakukan identifikasi terhadap tujuan dan proses TI di BPMPTSP Bone Bolango, kemudian dipetakan dengan kerangka tata kelola TI COBIT 5. Hasil dari pemetaan tersebut adalah proses TI "Optimalisasi Aset TI, Sumber Daya dan Kapabilitas" sebagai hasil penelitian.

Penelitian tahun 2018 yang berjudul "IT Governance Audit with COBIT 5 Framework on DSS Domain" [8] melakukan penelitian terkait audit tata kelola teknologi informasi pada suatu perusahaan menggunakan framework Cobit 5 pada domain DSS (Deliver, Service, and Support) dan berfokus pada sub domain DSS01 Manage Operations, DSS02 Manage Service Requests and Incidents, DSS03 Manage Problems, dan DSS06 Manage Business Process Controls. Metode penilaian yang digunakan pada penelitian ini yaitu model kapabilitas yang terdiri dari lima tingkat kemampuan. Hasil pada penelitian ini menyatakan rata-rata tingkat kapabilitas dari keseluruhan proses yang diperoleh sebagian besar proses telah mencapai level 1 proses yang dilakukan.

Penelitian tentang evaluasi tata kelola TI tahun 2019 yang berjudul "IT Governance Evaluation using Cobit 5 Framework on the National Library" membahas tentang tata kelola TI yang pada National Library of Indonesia (NLI) [9]. Metode yang digunakan pada penelitian ini adalah metode kualitatif dengan melakukan wawancara dan observasi agar penulis dapat mengumpulkan data secara bersamaan. Data yang didapat dari observasi dan wawancara kemudian diproses dan dihitung berdasarkan tingkat kapabilitas pada COBIT 5.

Penelitian yang berjudul "Audit Tata Kelola Teknologi Informasi pada Sistem Informasi Akademik Menggunakan Framework COBIT 5"[10] melakukan penelitin pada AMIK Master Lampung yang merupakan salah satu perguruan tinggi swasta di Bandar Lampung. Tujuan dari penelitian ini adalah untuk mengoptimalkan pengawasan dari bagian IT dalam pelaksanaan sistem informasi akademik (SIAKAD) karena banyaknya keluhan dari penggunanya. Penelitian ini dimulai dari tahap perencanaan dengan mengumpulkan data yang terdapat di AMIK Master Lampung untuk menentukan bagian-bagian apa saja yang terlibat dalam penggunaan Sistem Informasi Akademik dan dilakukan pengauditan yang kemudian di evaluasi menggunakan model COBIT 5 dengan menggunakan domain DSS (Deliver, Service, and Support) dan MEA (Monitoring, Evaluate and Assess). Hasil penelitian menunjukkan Capability level seluruh domain berada pada level 3 namun Capability level yang diharapkan ada pada level 4.

Penelitian mengenai audit tata kelola TI juga dilakukan oleh Ricky Perdana Kusuma yang pada penelitiannya melakukan audit tata kelola TI di Konsultan Manajemen Pusat menggunakan Framework COBIT 5[11]. Penelitian yang dilakukan oleh Ricky Perdana Kusuma ini menggunakna metode deskriptif kualitatif serta kuisioner dan pendekatan survei dalam proses pengumpulan data. Proses 
selanjutnya pada penelitian ini adalah menentukan Capability level berdasarkan COBIT 5 dengan domain DSS. Hasil dari penelitian ini diperoleh dua proses domain yaitu DSS02 dan DSS05 yang mempunyai tingkat kapablitias bernilai satu.

Penelitian yang berjudul "IS Governance Evaluation Using COBIT 5 Framework on the Central Statistics Agency of Banyumas District"[12] melakukan evaluasi tata kelola menggunakan kerangka kerja COBIT 5 pada Kantor Badan Pusat Statistik Kabupaten Banyumas. Penelitian ini menggunakan metode kuantitatif dan metode kualitatif, yang dilanjutkan dengan menentukan Capability level berdasarkan COBIT 5 dengan domain EDM. Hasil yang diperoleh pada penelitian ini menunjukkan indeks kematangan saat ini dengan nilai 3,25 dan tergolong Capability level 3 yang menunjukan bahwa sistem informasi pada BPS sudah berjalan dengan baik serta peggunaan sistem informasi yang efisien.

Penelitian tahun 2019 yang berjudul "Audit Layanan SKA (Surat Keterangan Asal) Untuk Barang Ekspor Menggunakan Framework COBIT 5" (Ngurah Aditya Winata, dkk , 2019). Penelitian ini dilakukan pada instansi IPSKA Bali (Institusi Penerbit Surat Keterangan Asal Provinsi Bali ) dengan metode pengumpulan data dengan melakukan wawancara, Kuisioner dan observasi. Hasil yang didapat pada domain terdapat 5 proses TI tertinggi yaitu EDM05, AP07, DSS02, DSS03, dan DSS06 yang mencapai status largely achieved pada masing-masing domain.

Kesimpulan yang dapat diambil berdasarkan penelitian yang dipaparkan diatas menyatakan bahwa audit tata kelola teknologi informasi sangat penting dilakukan oleh suatu organisasi untuk mendukung tata kelola teknologi informasi terkait kecepatan dan ketepatan hasil agar dapat mencapai visi dan misi organisasi. Berdasarkan penelitian yang sudah ada sebelumnya, dalam penelitian ini memiliki perbedaan yaitu untuk mendapatkan tujuan organisasi penulis menggunakan indikator kerja program yang terdapat pada Renstra Dinas Pariwisata Kabupaten X tahun 2016-2021.

COBIT 5 menyediakan kerangka kerja komprehensif yang membantu perusahaan dalam mencapai tujuan mereka untuk tata kelola dan manajemen TI perusahaan. Secara sederhana, ini membantu perusahaan menciptakan nilai optimal dari TI dengan menjaga keseimbangan antara menyadari manfaat dan mengoptimalkan tingkat risiko dan penggunaan sumber daya. COBIT 5 memungkinkan TI untuk diatur dan dikelola secara holistik untuk seluruh perusahaan, mengambil dalam bisnis ujung ke ujung penuh dan area tanggung jawab fungsional TI, dengan mempertimbangkan kepentingan terkait TI dari pemangku kepentingan internal dan eksternal. COBIT 5 bersifat umum dan berguna untuk perusahaan dari semua ukuran, baik komersial, nirlaba, atau di sektor publik.

COBIT 5 memperkenalkan adanya capability model yang berdasarkan pada ISO/IEC 15504, standar mengenai Software Engineering dan Process Assessment. Model ini mengukur performansi tiap proses tata kelola (EDM-based) atau proses manajemen (PBRM based), dan dapat mengidentifikasi area-area yang perlu untuk ditingkatkan performansinya. Model ini berbeda dengan model proses maturity dalam COBIT 4.1, baik itu pada desain maupun penggunaanya[14] .

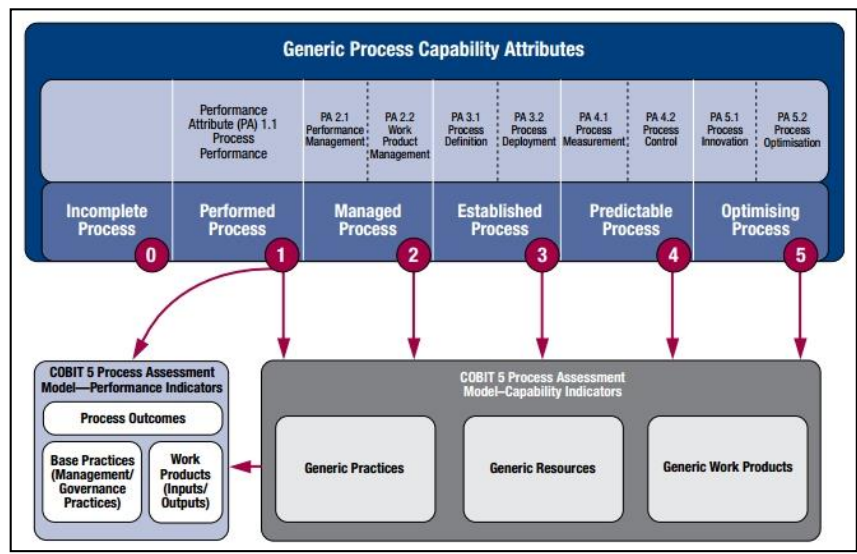

Gambar. 1. Generic Process Capability Attributes (A Business Framework for the Governance and Management of Enterprise IT)

Gambar 1 merupakan model dari generic process capability attributes pada COBIT 5 . Capability yang dapat dicapai oleh masing-masing proses terdiri enam tingkatan yaitu sebagai berikut[15].

- Level 0 Incomplete Process - Proses tidak lengkap; Proses tidak diimplementasikan atau gagal mencapai tujuannya. Pada tingkatan ini, hanya ada sedikit bukti atau bahkan tidak ada bukti adanya pencapaian sistematik dari tujuan proses tersebut.

- Level 1 Performed Process (one attribute) - Proses sudah dijalankan; Proses yang diimplementasikan telah berhasil mencapai tujuannya.

- Level 2 Managed Process (two attributes) - Proses teratur (dua atribut); Proses yang telah dijalankan dan telah diimplementasikan dalam cara yang lebih teratur (direncanakan, dipantau, dan disesuaikan), dan output dari proses yang dihasilkan telah ditetapkan, dikendalikan, dan dijaga dengan baik.

- Level 3 Established Process (two attributes) - Proses telah diimplementasikan menggunakan standar SOP yang telah ditetapkan, yang mampu mencapai outcome yang diharapkan.

- Level 4 Predictable Process (two attributes) - Proses dijalankan menggunakan standar SOP yang ditetapkan, serta proses dan hasilnya dapat diprediksi dalam batasan waktu yang ditentukan.

- Level 5 Optimising Process (two attributes) - Kinerja proses terus ditingkatkan secara berkelanjutan untuk memenuhi tujuan bisnis saat ini dan masa depan.

COBIT 5 bersifat umum dan berguna untuk segala jenis ukuran perusahaan, baik sektor komersial, sektor nonprofit, sektor pemerintahan atau pada sektor public. COBIT 5 didasarkan pada lima prinsip kunci untuk tata kelola dan manajemen TI perusahaan. Suryono[16] menyatakan lima prinsip COBIT 5 memungkinkan perusahaan untuk membangun sebuah kerangka tata kelola dan manajemen 
yang efektif, yang dapat mengoptimalkan investasi dan penggunaan TI untuk mendapatkan keuntungan bagi para stakeholder.

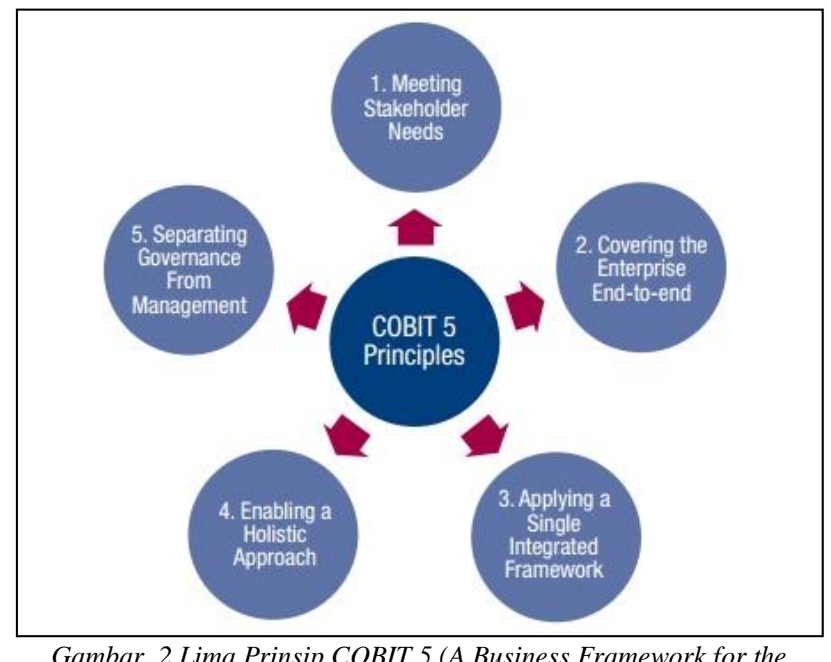

Gambar. 2 Lima Prinsip COBIT 5 (A Business Framework for the Governance and Management of Enterprise IT)

Gambar 2 merupakan lima prinsip utama dalam COBIT 5. Lima prinsip COBIT 5 diantaranya.

- Memenuhi Kebutuhan Stakeholder (Meeting Stakeholder Need)

- Melingkupi Seluruh Perusahaan (Covering the Enterprise End-to-end)

- Menerapkan Suatu Kerangka Tunggal yang Terintegrasi (Applying a Single Integrated Framework)

- Menggunakan Pendekatan yang Menyeluruh (Enabling a Holistic Approach)

Pemisahan Tata Kelola dari Manajemen (Separating Governance From Management).

\section{METODE PENELITIAN}

Metodologi penelitian merupakan proses yang ditetapkan dalam melakukan penelitian audit. Gambaran umum tahapan penelitian audit tata kelola teknologi informasi pada Dinas Pariwisata Kabupaten X menggunakan framework COBIT 5 dapat dilihat pada Gambar 1.

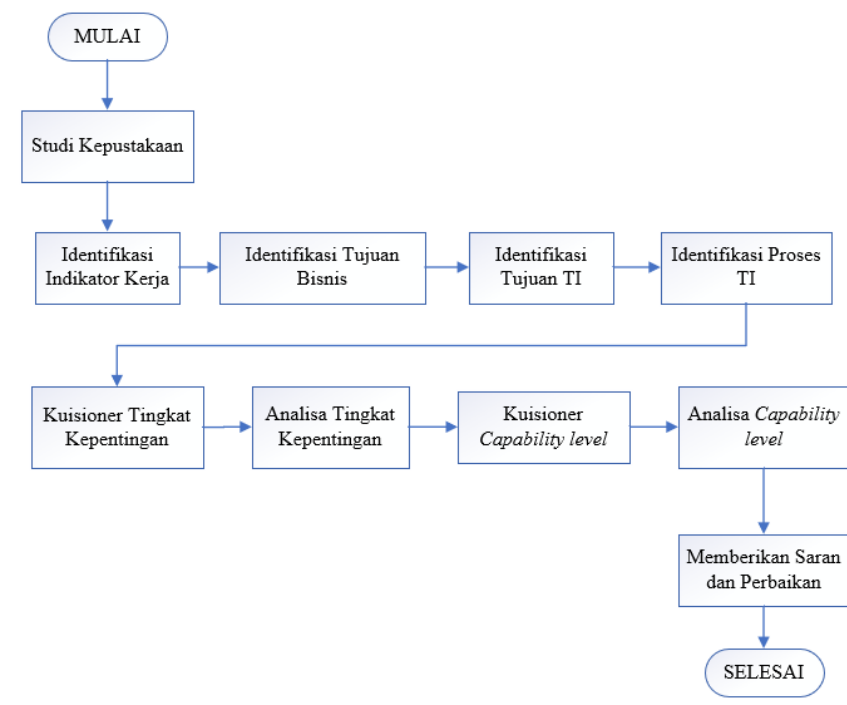

Gambar. 3. Tahapan Penelitian

Gambar 3 merupakan tahapan penelitian audit tata kelola teknologi informasi pada Dinas Pariwisata Kabupaten X yaitu penentuan studi kepustakaan, identifikasi indikator kerja melalui Renstra Dinas Pariwisata Kabupaten X dan wawancara narasumber atau pegawai, pencarian tingkat kepentingan, pencarian Capability level pemberian saran dan perbaikan, serta kesimpulan. Tahapan penelitian menggunakan framework COBIT 5 terkait dengan Capability level pada Dinas Pariwisata Kabupaten X digunakan sebagai acuan dalam penyusunan kuesioner. Hasil kuesioner digunakan sebagai sumber data untuk mengukur Capability level pada Dinas Pariwisata Kabupaten X dan menentukan target Capability level serta menentukan GAP untuk memberikan rekomendasi perbaikan pada layanan instansi pemerintah.

\section{A. Studi Kepustakaan}

Studi kepustakaan merupakan langkah awal dalam melakukan penelitian dengan cara pengumpulan data dan informasi melalui berbagai sumber pustaka. Sumber pustaka dapat diperoleh melalui buku, jurnal ilmiah, internet, pakar dan lain sebagainya. Proses ini juga melakukan pengumpulan informasi serta teori-teori yang relevan dari penelitian sebelumnya yang terkait tentang tata kelola teknologi informasi dan framework COBIT 5. Data dan informasi yang telah dikumpulkan akan memperkuat dasar teori yang digunakan dalam penelitian dan penulisan laporan penelitian.

\section{B. Identifikasi Indikator Kerja}

Identifikasi indikator kerja merupakan turunan dari visi dan misi yang dimiliki suatu organisasi. Visi dan misi mencerminkan tujuan dari organisasi akan tetapi visi dan misi bersifat luas sehingga perlu dilakukan proses penyempitan menggunakan indikator kerja. COBIT dalam panduannya memetakan visi dan misi sehingga mendapatkan cangkupan evaluasi yang akan dilakukan. Penelitian ini menggunakan indikator program kerja yang termuat dalam RESTRA 
(Rencana Strategis) yang dimiliki Dinas Pariwisata Kabupaten X Tahun 2016-2021

\section{Proses Pemilihan Domain}

Proses pemilihan domain dalam penelitian ditentukan berdasarkan pemetaan dari identifikasi tujuan bisnis, identifikasi tujuan TI, dan identifikasi proses TI. Berikut merupakan rincian penjelasan mengenai proses yang dilakukan dalam pemilihan domain pada COBIT 5.

1) Identifikasi Tujuan Bisnis

Identifikasi tujuan bisnis dalam suatu organisasi dapat dilakukan dengan mendefinisikan proses bisnis yang sedang bejalan baik proses bisnis utama maupun proses bisnis pendukung organisasi. COBIT mengelompokkan tujuan bisnis menjadi empat buah perspektif yang mewakili daftar dari tujuan suatu organisasi. Berikut merupakan pemaparan tujuan bisnis organisasi yang dapat dilihat pada Tabel 1.

TABEL 1. TUJUAN BISNIS COBIT 5

\begin{tabular}{|c|c|c|}
\hline Perspektif Kinerja & No. & $\begin{array}{c}\text { Tujuan Bisnis } \\
\end{array}$ \\
\hline \multirow{5}{*}{ Perspektif Keuangan } & 1. & Nilai stakeholder dari investasi bisnis \\
\hline & 2. & $\begin{array}{l}\text { Portofolio dari produk dan servis yang } \\
\text { kompetitif }\end{array}$ \\
\hline & 3. & $\begin{array}{l}\text { Pengelolaan resiko bisnis terutama } \\
\text { pengamanan aset }\end{array}$ \\
\hline & 4. & $\begin{array}{l}\text { Kepatuhan terhadap hukum dan } \\
\text { pertaturan eksternal }\end{array}$ \\
\hline & 5. & Transparansi keuangan \\
\hline \multirow{5}{*}{ Perspektif Pelanggan } & 6. & Berorientasi kepada budaya pelanggan \\
\hline & 7. & $\begin{array}{l}\text { Ketersediaan layanan bisnis yang } \\
\text { berkelanjutan }\end{array}$ \\
\hline & 8. & $\begin{array}{l}\text { Respon yang cepat terhadap } \\
\text { lingkungan bisnis yang berubah }\end{array}$ \\
\hline & 9. & $\begin{array}{l}\text { Strategi pengambilan keputusan } \\
\text { berdasarkan informasi yang ada }\end{array}$ \\
\hline & 10. & Optimisasi biaya pelayanan \\
\hline \multirow{5}{*}{ Perspektif Internal } & 11. & Optimisasi fungsi bisnis proses \\
\hline & 12. & Optimisasi biaya bisnis proses \\
\hline & 13. & $\begin{array}{l}\text { Mengelola program bisnis yang } \\
\text { berubah }\end{array}$ \\
\hline & 14. & Staf dan operasional yang produktif \\
\hline & 15. & Kepatuhan terhadap kebijakan internal \\
\hline \multirow{2}{*}{$\begin{array}{c}\text { Perspektif } \\
\text { Pembelajaran \& } \\
\text { Pertumbuhan }\end{array}$} & 16. & Pegawai yang terampil dan termotivasi \\
\hline & 17. & $\begin{array}{l}\text { Produk dan inovasi bisnis berdasarkan } \\
\text { budaya }\end{array}$ \\
\hline
\end{tabular}

(Sumber: COBIT 5 A Business Framework for the Governance and Management of Enterprise IT," telah diolah kembali", h.19)

Tabel 1 merupakan pemaparan dari tujuan bisnis berdasarkan buku acuan COBIT 5 A Business Framework for the Government and Management of Enterprise IT. Identifikasi tujuan bisnis dalam buku acuan COBIT 5 merupakan empat perspektif kinerja dalam Balanced Scorecard yaitu perspektif keuangan, perspektif pelanggan, perspektif proses bisnis internal serta perspektif pembelajaran dan pertumbuhan.

\section{2) Identifikasi Tujuan TI}

Identifikasi tujuan TI merupakan proses yang dilakukan setelah mengetahui tujuan bisnis suatu organisasi sehingga dapat dilakukan pemetaan hasil dari tujuan bisnis suatu organisasi dengan tujuan TI yang digunakan sebagai acaun suatu organisasi dalam mendefinisikan kebutuhan bisnis dengan ketersediaan teknologi informasi. Berikut merupakan pemaparan tujuan TI yang dikelompokkan menjadi empat buah perspektif yang berbeda berdasarkan kerangka kerja COBIT 5 yang dapat dilihat pada table 2

TABEL 2. TUJUAN TI COBIT 5

\begin{tabular}{|c|c|c|}
\hline $\begin{array}{l}\text { Perspektif } \\
\text { Kinerja TI }\end{array}$ & No. & Tujuan TI \\
\hline \multirow{6}{*}{$\begin{array}{l}\text { Perspektif } \\
\text { Keuangan }\end{array}$} & 1. & Penyelarasan TI dengan strategi bisnis \\
\hline & 2. & $\begin{array}{l}\text { Kepatuhan TI serta dukungan untuk } \\
\text { kepatuhan peraturan serta hukum eksternal }\end{array}$ \\
\hline & 3. & $\begin{array}{l}\text { Komitmen dari manajemen eksekutif untuk } \\
\text { membuat keputusan yang berkaitan dengan } \\
\text { TI }\end{array}$ \\
\hline & 4. & $\begin{array}{l}\text { Menangani masalah TI yang terkait resiko } \\
\text { bisnis }\end{array}$ \\
\hline & 5. & $\begin{array}{l}\text { Menyadari adanya manfaat dari } \\
\text { diberdayakannya investasi pada bidang TI } \\
\text { dan layanan portofolio }\end{array}$ \\
\hline & 6. & $\begin{array}{l}\text { Transparansi pada biaya, manfaat, serta } \\
\text { resiko TI }\end{array}$ \\
\hline \multirow{2}{*}{$\begin{array}{l}\text { Perspektif } \\
\text { Pelanggan }\end{array}$} & 7. & $\begin{array}{l}\text { Pengiriman layanan TI yang sesuai dengan } \\
\text { kebutuhan bisnis }\end{array}$ \\
\hline & 8. & $\begin{array}{l}\text { Penggunaan aplikasi, informasi, dan solusi } \\
\text { teknologi yang memadai }\end{array}$ \\
\hline \multirow{7}{*}{$\begin{array}{l}\text { Perspektif } \\
\text { Internal }\end{array}$} & 9. & Ketangkasan TI \\
\hline & 10. & $\begin{array}{l}\text { Keamanan informasi, } \\
\text { infrastruktur dan aplikasi }\end{array}$ \\
\hline & 11. & $\begin{array}{l}\begin{array}{l}\text { Optimisasi aset, sumber daya serta } \\
\text { kemampuan TI }\end{array} \\
\end{array}$ \\
\hline & 12. & $\begin{array}{l}\text { Pemberdayaan dan dukungan dari bisnis } \\
\text { proses dengan cara mengintegrasikan } \\
\text { aplikasi dan teknologi ke dalam bisnis } \\
\text { proses }\end{array}$ \\
\hline & 13. & $\begin{array}{l}\text { Pengiriman program yang memberikan } \\
\text { manfaat, tepat waktu, sesuai anggaran, serta } \\
\text { memenuhi persyaratan dan standar kualitas }\end{array}$ \\
\hline & 14. & $\begin{array}{l}\text { Ketersediaan informasi yang dapat } \\
\text { dipercaya dan bermanfaat bagi pengambilan } \\
\text { keputusan }\end{array}$ \\
\hline & 15. & Kepatuhan TI terhadap kebijakan internal \\
\hline \multirow{2}{*}{$\begin{array}{l}\text { Perspektif } \\
\text { Pembelajaran \& } \\
\text { Pertumbuhan }\end{array}$} & 16. & $\begin{array}{l}\text { Personil TI yang kompeten serta memiliki } \\
\text { motivasi terhadap bisnis yang ada }\end{array}$ \\
\hline & 17. & $\begin{array}{l}\text { Pengetahuan, keahlian, dan inisiatif untuk } \\
\text { inovasi bisnis }\end{array}$ \\
\hline
\end{tabular}

Tabel 2 merupakan pemaparan dari tujuan TI berdasarkan buku acuan COBIT 5 A Business Framework for the Government and Management of Enterprise IT. Tujuan TI dalam buku acuan COBIT 5 memiliki total keseluruhan 17 tujuan yang dibagi ke dalam empat perspektif kinerja TI meliputi perspektif keuangan, perspektif pelanggan, perspektif internal dan perspektif pembelajaran dan pertumbuhan. COBIT 5 menyediakan keterkaitan antara tujuan bisnis dan tujuan TI yang mendukung setiap tujuan bisnis yang dipilih serta menyediakan semua proses yang dibutuhkan untuk penciptaan nilai bisnis melalui penggunaan TI. Berikut merupakan keterkaitan antara tujuan bisnis dan tujuan TI berdasarkan COBIT 5 dapat dilihat pada Tabel 3.

TABEL 3. PEMETAAN TUJUAN BISNIS DAN TUJUAN TI 


\begin{tabular}{|c|c|c|c|c|c|c|c|c|}
\hline $\begin{array}{c}\text { Perspektif } \\
\text { Kinerja }\end{array}$ & $\begin{array}{c}\text { No } \\
\text {. }\end{array}$ & $\begin{array}{c}\text { Tujuan } \\
\text { Bisnis }\end{array}$ & \multicolumn{6}{|c|}{$\begin{array}{c}\text { Tujuan TI yang Utama } \\
\text { (Primary) }\end{array}$} \\
\hline \multirow{5}{*}{$\begin{array}{l}\text { Perspektif } \\
\text { Keuangan }\end{array}$} & 1. & $\begin{array}{l}\text { Nilai } \\
\text { stakeholder } \\
\text { dari investasi } \\
\text { bisnis }\end{array}$ & 1 & 3 & 5 & 7 & $\begin{array}{l}1 \\
1\end{array}$ & $\begin{array}{l}1 \\
3\end{array}$ \\
\hline & 2. & $\begin{array}{l}\text { Portofolio } \\
\text { dari produk } \\
\text { dan servis } \\
\text { yang } \\
\text { kompetitif }\end{array}$ & 1 & 5 & 7 & 9 & $\begin{array}{l}1 \\
2\end{array}$ & $\begin{array}{l}1 \\
7\end{array}$ \\
\hline & 3. & $\begin{array}{l}\text { Pengelolaan } \\
\text { resiko bisnis } \\
\text { terutama } \\
\text { pengamanan } \\
\text { aset }\end{array}$ & 4 & $\begin{array}{l}1 \\
0\end{array}$ & $\begin{array}{l}1 \\
6\end{array}$ & & & \\
\hline & 4. & $\begin{array}{l}\text { Kepatuhan } \\
\text { terhadap } \\
\text { hukum dan } \\
\text { peraturan } \\
\text { eksternal }\end{array}$ & 2 & $\begin{array}{l}1 \\
0\end{array}$ & & & & \\
\hline & 5. & $\begin{array}{l}\text { Transparansi } \\
\text { keuangan }\end{array}$ & 6 & & & & & \\
\hline \multirow{5}{*}{$\begin{array}{l}\text { Perspektif } \\
\text { Pelanggan }\end{array}$} & 6. & $\begin{array}{l}\text { Berorientasi } \\
\text { kepada } \\
\text { budaya } \\
\text { pelanggan }\end{array}$ & 1 & 7 & & & & \\
\hline & 7. & $\begin{array}{l}\text { Ketersediaan } \\
\text { layanan } \\
\text { bisnis yang } \\
\text { berkelanjuta } \\
\mathrm{n}\end{array}$ & 4 & $\begin{array}{l}1 \\
0\end{array}$ & $\begin{array}{l}1 \\
4\end{array}$ & & & \\
\hline & 8. & $\begin{array}{l}\text { Respon yang } \\
\text { cepat } \\
\text { terhadap } \\
\text { lingkungan } \\
\text { bisnis yang } \\
\text { berubah }\end{array}$ & 1 & 7 & 9 & $\begin{array}{l}1 \\
7\end{array}$ & & \\
\hline & 9. & $\begin{array}{l}\text { Strategi } \\
\text { pengambilan } \\
\text { keputusan } \\
\text { berdasarkan } \\
\text { informasi } \\
\text { yang ada }\end{array}$ & 1 & $\begin{array}{l}1 \\
4\end{array}$ & & & & \\
\hline & 10. & $\begin{array}{l}\text { Optimisasi } \\
\text { biaya } \\
\text { pelayanan }\end{array}$ & 4 & 6 & $\begin{array}{l}1 \\
1\end{array}$ & & & \\
\hline \multirow{5}{*}{$\begin{array}{l}\text { Perspektif } \\
\text { Internal }\end{array}$} & 11. & $\begin{array}{l}\text { Optimisasi } \\
\text { fungsi bisnis } \\
\text { proses }\end{array}$ & 1 & 7 & 8 & 9 & $\begin{array}{l}1 \\
2\end{array}$ & \\
\hline & 12. & $\begin{array}{l}\text { Optimisasi } \\
\text { biaya bisnis } \\
\text { proses }\end{array}$ & 5 & 6 & $\begin{array}{l}1 \\
1\end{array}$ & & & \\
\hline & 13. & $\begin{array}{l}\text { Mengelola } \\
\text { program } \\
\text { bisnis yang } \\
\text { berubah }\end{array}$ & 1 & 3 & $\begin{array}{l}1 \\
3\end{array}$ & & & \\
\hline & 14. & $\begin{array}{l}\text { Staf dan } \\
\text { operasional } \\
\text { yang } \\
\text { produktif }\end{array}$ & 8 & $\begin{array}{l}1 \\
6\end{array}$ & & & & \\
\hline & 15 . & $\begin{array}{l}\text { Kepatuhan } \\
\text { terhadap } \\
\text { kebijakan } \\
\text { internal }\end{array}$ & 2 & $\begin{array}{l}1 \\
0\end{array}$ & $\begin{array}{l}1 \\
5\end{array}$ & & & \\
\hline \multirow[t]{2}{*}{$\begin{array}{c}\text { Perspektif } \\
\text { Pembelajara } \\
\text { n \& } \\
\text { Pertumbuhan }\end{array}$} & 16. & $\begin{array}{l}\text { Pegawai } \\
\text { yang } \\
\text { terampil dan } \\
\text { termotivasi }\end{array}$ & $\begin{array}{l}1 \\
6\end{array}$ & & & & & \\
\hline & 17. & Produk dan & 9 & 1 & & & & \\
\hline
\end{tabular}

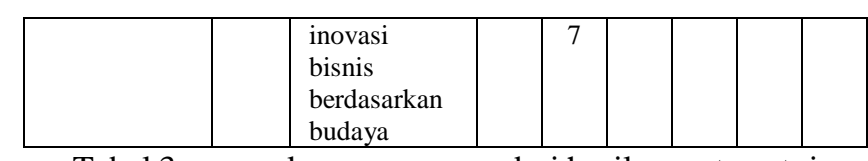

Tabel 3 merupakan pemaparan dari hasil pemetaan tujuan bisnis dan tujuan TI berdasarkan buku acuan COBIT $5 \mathrm{~A}$ Business Framework for the Government and Management of Enterprise IT

\section{3) Identifikasi Proses TI}

Identifikasi proses TI merupakan tahapan dimana tujuan TI dibagi menjadi setiap proses TI yang saling berkaitan dengan pedoman COBIT, sehingga memberikan kemudahan dalam memahami keterkaitan antara tujuan bisnis dan tujuan TI yang telah dilakukan sebelumnya. Berikut merupakan pemetaan antara tujuan TI dan proses TI dalam kerangka kerja COBIT 5 dapat dilihat pada Tabel 4.

TABEL 4. PEMETAAN TUJUAN TI DENGAN PROSES TI

\begin{tabular}{|c|c|c|c|c|c|c|}
\hline \multirow{2}{*}{$\begin{array}{c}\text { No } \\
\text {. }\end{array}$} & \multirow{2}{*}{ Tujuan TI } & \multicolumn{5}{|c|}{ Proses TI } \\
\hline & & EDM & APO & BAI & DSS & MEA \\
\hline 1. & $\begin{array}{l}\text { Penyelarasan } \\
\text { TI dengan } \\
\text { strategi bisnis }\end{array}$ & $\begin{array}{c}\text { EDM0 } \\
1 \\
\text { EDM0 } \\
2\end{array}$ & $\begin{array}{c}\text { APOO } \\
1 \\
\text { APO0 } \\
2 \\
\text { APO0 } \\
3 \\
\text { APO0 } \\
5 \\
\text { APO0 } \\
7 \\
\text { APO0 } \\
8\end{array}$ & $\begin{array}{c}\text { BAI0 } \\
1 \\
\text { BAI0 } \\
2\end{array}$ & & \\
\hline 2. & $\begin{array}{l}\text { Kepatuhan TI } \\
\text { serta dukungan } \\
\text { untuk } \\
\text { kepatuhan } \\
\text { peraturan serta } \\
\text { hukum } \\
\text { eksternal }\end{array}$ & & $\begin{array}{c}\text { APO0 } \\
1 \\
\text { APO1 } \\
2 \\
\text { APO1 } \\
3\end{array}$ & $\begin{array}{c}\text { BAI1 } \\
0\end{array}$ & $\begin{array}{c}\text { DSS0 } \\
5\end{array}$ & $\begin{array}{c}\text { MEA0 } \\
2\end{array}$ \\
\hline 3. & $\begin{array}{l}\text { Komitmen dari } \\
\text { manajemen } \\
\text { eksekutif untuk } \\
\text { membuat } \\
\text { keputusan yang } \\
\text { berkaitan } \\
\text { dengan TI }\end{array}$ & $\begin{array}{c}\text { EDM0 } \\
1 \\
\text { EDM0 } \\
5\end{array}$ & & & & $\begin{array}{c}\text { MEA0 } \\
3\end{array}$ \\
\hline 4. & $\begin{array}{l}\text { Menangani } \\
\text { masalah TI } \\
\text { yang terkait } \\
\text { resiko bisnis }\end{array}$ & & $\begin{array}{l}\text { APO1 } \\
0 \\
\text { APO1 } \\
2 \\
\text { APO1 } \\
3\end{array}$ & $\begin{array}{c}\text { BAI0 } \\
1 \\
\text { BAI0 } \\
6\end{array}$ & $\begin{array}{c}\text { DSS0 } \\
1 \\
\text { DSS0 } \\
2 \\
\text { DSS0 } \\
3 \\
\text { DSS0 } \\
4 \\
\text { DSS0 } \\
5 \\
\text { DSS0 } \\
6\end{array}$ & $\begin{array}{c}\text { MEA0 } \\
1 \\
\text { MEA0 } \\
2 \\
\text { MEA0 } \\
3\end{array}$ \\
\hline 5. & $\begin{array}{l}\text { Menyadari } \\
\text { adanya } \\
\text { manfaat dari } \\
\text { diberdayakann } \\
\text { ya investasi } \\
\text { pada bidang TI }\end{array}$ & & $\begin{array}{c}\text { APO0 } \\
4 \\
\text { APO0 } \\
5 \\
\text { APO0 } \\
6\end{array}$ & $\begin{array}{c}\text { BAI0 } \\
1\end{array}$ & & \\
\hline
\end{tabular}




\begin{tabular}{|c|c|c|c|c|c|c|}
\hline & $\begin{array}{l}\text { dan layanan } \\
\text { portofolio }\end{array}$ & & $\begin{array}{c}\text { APO1 } \\
1\end{array}$ & & & \\
\hline 6. & $\begin{array}{l}\text { Transparansi } \\
\text { pada biaya, } \\
\text { manfaat, serta } \\
\text { resiko TI }\end{array}$ & $\begin{array}{c}\text { EDM0 } \\
5\end{array}$ & $\begin{array}{c}\text { APO0 } \\
6 \\
\text { APO1 } \\
2 \\
\text { APO1 } \\
3\end{array}$ & $\begin{array}{c}\text { BAI0 } \\
9\end{array}$ & & \\
\hline 7. & $\begin{array}{l}\text { Pengiriman } \\
\text { layanan TI } \\
\text { yang sesuai } \\
\text { dengan } \\
\text { kebutuhan } \\
\text { bisnis }\end{array}$ & $\begin{array}{c}\text { EDM0 } \\
5\end{array}$ & $\begin{array}{c}\mathrm{APO} 0 \\
2 \\
\mathrm{APO} 0 \\
8 \\
\mathrm{APO} 0 \\
9 \\
\mathrm{APO} 1 \\
0 \\
\mathrm{APO} 1 \\
1\end{array}$ & $\begin{array}{c}\text { BAI0 } \\
2 \\
\text { BAI0 } \\
3 \\
\text { BAI0 } \\
4 \\
\text { BAI0 } \\
6\end{array}$ & $\begin{array}{c}\text { DSS0 } \\
1 \\
\text { DSS0 } \\
2 \\
\text { DSS0 } \\
3 \\
\text { DSS0 } \\
4 \\
\text { DSS0 } \\
6\end{array}$ & $\begin{array}{c}\text { MEA0 } \\
1\end{array}$ \\
\hline 8. & $\begin{array}{l}\text { Penggunaan } \\
\text { aplikasi, } \\
\text { informasi, dan } \\
\text { solusi } \\
\text { teknologi yang } \\
\text { memadai }\end{array}$ & & $\begin{array}{c}\mathrm{APO} 0 \\
4\end{array}$ & $\begin{array}{l}\text { BAI0 } \\
5 \\
\text { BAI0 } \\
7\end{array}$ & & \\
\hline 9. & $\begin{array}{l}\text { Ketangkasan } \\
\text { TI }\end{array}$ & $\begin{array}{c}\text { EDM0 } \\
4\end{array}$ & $\begin{array}{c}\mathrm{APO} 0 \\
1 \\
\mathrm{APO} 0 \\
3 \\
\mathrm{APO} 0 \\
4 \\
\mathrm{APO} 1 \\
0\end{array}$ & $\begin{array}{c}\text { BAI0 } \\
8\end{array}$ & & \\
\hline 10. & $\begin{array}{l}\text { Keamanan } \\
\text { informasi, } \\
\text { pemrosesan } \\
\text { infrastruktur } \\
\text { dan aplikasi }\end{array}$ & & $\begin{array}{l}\text { APO1 } \\
2 \\
\text { APO1 } \\
3\end{array}$ & $\begin{array}{c}\text { BAI0 } \\
6\end{array}$ & $\begin{array}{l}\text { DSS0 } \\
5\end{array}$ & \\
\hline 11. & $\begin{array}{l}\text { Optimisasi } \\
\text { aset, sumber } \\
\text { daya serta } \\
\text { kemampuan TI }\end{array}$ & $\begin{array}{c}\text { EDM0 } \\
4\end{array}$ & $\begin{array}{c}\mathrm{APO} 0 \\
1 \\
\mathrm{APO} 0 \\
3 \\
\mathrm{APO} 0 \\
4 \\
\mathrm{APO} 0 \\
7\end{array}$ & $\begin{array}{c}\text { BAI0 } \\
4 \\
\text { BAI0 } \\
9 \\
\text { BAI1 } \\
0\end{array}$ & $\begin{array}{c}\text { DSS0 } \\
3\end{array}$ & $\begin{array}{c}\text { MEA0 } \\
1\end{array}$ \\
\hline 12. & $\begin{array}{l}\text { Pemberdayaan } \\
\text { dan dukungan } \\
\text { dari bisnis } \\
\text { proses dengan } \\
\text { cara } \\
\text { mengintegrasik } \\
\text { an aplikasi dan } \\
\text { teknologi ke } \\
\text { dalam bisnis } \\
\text { proses }\end{array}$ & & $\begin{array}{c}\text { APO0 } \\
8\end{array}$ & $\begin{array}{c}\text { BAI0 } \\
2 \\
\text { BAI0 } \\
7\end{array}$ & & \\
\hline 13. & $\begin{array}{l}\text { Pengiriman } \\
\text { program yang } \\
\text { memberikan } \\
\text { manfaat, tepat } \\
\text { waktu, sesuai } \\
\text { anggaran, serta } \\
\text { memenuhi } \\
\text { persyaratan } \\
\text { dan standar } \\
\text { kualitas }\end{array}$ & & $\begin{array}{c}\mathrm{APO} 0 \\
5 \\
\mathrm{APO} 0 \\
7 \\
\mathrm{APO} 1 \\
1 \\
\mathrm{APO} 1 \\
2\end{array}$ & $\begin{array}{c}\text { BAI0 } \\
1 \\
\text { BAI0 } \\
5\end{array}$ & & \\
\hline 14. & $\begin{array}{l}\text { Ketersediaan } \\
\text { informasi yang } \\
\text { dapat } \\
\text { dipercaya dan } \\
\text { bermanfaat } \\
\text { bagi }\end{array}$ & & $\begin{array}{l}\text { APO0 } \\
9 \\
\text { APO1 } \\
3\end{array}$ & $\begin{array}{c}\text { BAI0 } \\
4 \\
\text { BAI1 } \\
0\end{array}$ & $\begin{array}{c}\text { DSS0 } \\
3 \\
\text { DSS0 } \\
4\end{array}$ & \\
\hline
\end{tabular}

\begin{tabular}{|c|c|c|c|c|c|}
\hline & $\begin{array}{l}\text { pengambilan } \\
\text { keputusan }\end{array}$ & & & & \\
\hline 15. & $\begin{array}{l}\text { Kepatuhan TI } \\
\text { terhadap } \\
\text { kebijakan } \\
\text { internal }\end{array}$ & & $\begin{array}{c}\text { APO0 } \\
1\end{array}$ & & $\begin{array}{l}\text { MEA0 } \\
1 \\
\text { MEA0 } \\
2 \\
\end{array}$ \\
\hline 16. & $\begin{array}{l}\text { Personil TI } \\
\text { yang kompeten } \\
\text { serta memiliki } \\
\text { motivasi } \\
\text { terhadap bisnis } \\
\text { yang ada }\end{array}$ & $\begin{array}{c}\text { EDM0 } \\
4\end{array}$ & $\begin{array}{c}\mathrm{APO} 0 \\
1 \\
\text { APO0 } \\
7\end{array}$ & & \\
\hline 17. & $\begin{array}{l}\text { Pengetahuan, } \\
\text { keahlian, dan } \\
\text { inisiatif untuk } \\
\text { inovasi bisnis }\end{array}$ & & $\begin{array}{c}\mathrm{APO} 0 \\
1 \\
\mathrm{APO} 0 \\
2 \\
\mathrm{APO} 0 \\
4 \\
\mathrm{APO} 0 \\
7 \\
\mathrm{APO} 0 \\
8\end{array}$ & $\begin{array}{l}\text { BAI0 } \\
5 \\
\text { BAI0 } \\
8\end{array}$ & \\
\hline
\end{tabular}

Tabel 4 merupakan pemaparan dari hasil pemetaan tujuan TI dengan proses TI berdasarkan buku acuan COBIT $5 \mathrm{~A}$ Business Framework for the Government and Management of Enterprise IT. Pemetaan pada tabel diatas didapatkan berdasarkan beberapa tujuan TI dan proses TI.

\section{Pengumpulan Data}

Pengumpulan data merupakan proses selanjutnya dalam melakukan audit. Metode pengumpulan data dilakukan untuk mendapatkan informasi yang akan mendukung penelitian. Pengumpulan data dilakukan terhadap staff dan top manajemen yang berhubungan langsung dengan program kerja yang sedang berjalan pada Dinas Pariwisata Kabupaten $\mathrm{X}$. Metode pengumpulan data yang digunakan dalam penelitian ini yaitu dokumentasi, wawancara dan kuesioner. Penjelasan mengenai metode pengumpulan data yaitu sebagai berikut.

1) Dokumentasi merupakan teknik pengumpulan data yang dilakukan melalui pengumpulan dokumen yang dimiliki organisasi yang dihimpum sesuai dengan tujuan dan fokus dari objek penelitian untuk memperoleh data langsung dari tempat penelitian.

2) Wawancara, yaitu metode pengumpulan data dengan mengajukan pertanyaan secara langsung kepada narasumber untuk mendapatkan data survei. Wawancara dilakukan untuk mengetahui visi, misi serta proses bisnis yang berjalan saat ini.

3) Kuesioner, merupakan metode pengumpulan data melalui formulir yang berisi pertanyaan yang diajukan secara tertulis kepada responden dengan tujuan untuk memperoleh informasi yang berkaitan dengan objek penelitian, dimana daftar pertanyaan dirancang secara detail dan lengkap, yang telah disesuaikan dengan kerangka kerja COBIT 5. Kuesioner akan disebarkan kepada jajaran top dan middle level management pada Dinas Pariwisata Kabupaten X, bertujuan untuk memperoleh informasi terkait tata kelola TI dan mengetahui current capability pada Dinas Pariwisata Kabupaten 
X. Kuesioner yang dibagikan adalah kuesioner tingkat kepentingan dan kuesioner tingkat kematangan.

\section{E. Responden}

Responden dari penelitian audit pada Dinas Pariwisata Kabupaten X adalah pihak yang terlibat dalam menjalankan program kerja yang termuat dalam RENSTRA Tahun 20162021. Responden dari tingkat kepentingan merupakan jajaran top dan middle level management. Tabel 5 merupakan penentuan responden untuk kuesioner tingkat kepentingan.

\section{TABEL 5. RESPONDEN KUESIONER TINGKAT KEPENTINGAN}

\begin{tabular}{|c|l|c|}
\hline No & \multicolumn{1}{|c|}{ Jabatan } & \\
\hline 1 & Kepala Dinas & 1 \\
\hline 2 & Sekretaris Dinas & 1 \\
\hline 3 & Kasub Bagian Umum dan Kepegawaian & 1 \\
\hline 4 & Kasub Bagian Keuangan & 1 \\
\hline 5 & Kasub Bagian Perencanaan dan Pelaporan & 1 \\
\hline 6 & Kepala Bidang Pengendalian Usaha Pariwisata & 1 \\
\hline 7 & Kepala Seksi Rumah Makan dan Restoran & 1 \\
\hline 8 & Kepala Seksi Sanitasi Lingkunga Pariwisata & 1 \\
\hline 9 & Kepala Seksi Akomodasi & 1 \\
\hline 10 & Kepala Bidang Obyek dan Data Tarik Pariwisata & 1 \\
\hline 11 & Kepala Seksi Daya Tarik Wisata & 1 \\
\hline 12 & Kepala Seksi Pelayanan Atraksi Wisata & 1 \\
\hline 13 & $\begin{array}{l}\text { Kepala Seksi Pelayanan Atraksi Wisata Rekreasi Dan } \\
\text { Hiburan Umum }\end{array}$ & 1 \\
\hline 14 & Kepala Bidang Promosi dan Pemasaran Pariwisata & 1 \\
\hline 15 & Kepla Seksi Pemasaran & 1 \\
\hline 16 & Kepala Seksi Event dan Pameran & 1 \\
\hline 17 & Kepala Seksi Pendataan Pariwisata & 1 \\
\hline 18 & Kepala Bidang Sumber Daya Pariwisata & 1 \\
\hline 19 & Kepala Seksi Pengembangan SDM Pariwisata & 1 \\
\hline 20 & Kepala Seksi Bimbingan Masyarakat Pariwisata & 1 \\
\hline 21 & $\begin{array}{l}\text { Kepala Seksi Bimbingan Kawasan dan Lingkungan } \\
\text { Total }\end{array}$ & 1 \\
\hline Tabiwata & mel & 21 \\
\hline
\end{tabular}

Tabel 5 merupakan daftar pihak yang menjadi responden dari kuesioner tingkat kematangan. Responden tingkat kematangan didapatkan berdasarkan hasil pemetaan RACI yang dilakukan dengan acuan COBIT 5.

\section{TABEL 6. RESPONDEN KUESIONER TINGKAT KEMATANGAN}

\begin{tabular}{|c|l|c|}
\hline No & \multicolumn{1}{|c|}{ Jabatan } & \\
\hline 1 & Kasub Bagian Umum dan Kepegawaian & 1 \\
\hline 2 & Kepala Bidang Pengendalian Usaha Pariwisata & 1 \\
\hline 3 & Kepala Bidang Obyek dan Daya Tarik Wisata & 1 \\
\hline 4 & Kepala Bidang Promosi dan Pemasaran Pariwisata & 1 \\
\hline 5 & Kepala Bidang Sumber Daya Pariwisata & 1 \\
\hline 6 & Kepala Seksi Daya Tarik Wisata & 1 \\
\hline 7 & Kepala Seksi Pelayanan Atraksi Wisata & 1 \\
\hline 8 & Kepala Seksi Rekreasi dan Hiburan Umum & 1 \\
\hline 9 & Kepala Seksi Pendataan Pariwisata & 1 \\
\hline 10 & Kepala Seksi Pengembangan SDM Pariwisata & 1 \\
\hline 11 & Kepala Seksi Bimbingan Masyarakat Pariwisata & 1 \\
\hline Total & & 11 \\
\hline
\end{tabular}

Tabel 6 merupakan responden dari kuesioner tingkat kapabilitas untuk menentukan dan mengetahui tingkat kematangan dari tata kelola TI pada Dinas Pariwisata.

F. Analisis Data

Analisis data dilakukan setelah semua data telah terkumpul, data tersebut berupa data hasil wawancara dan hasil kuesioner. Data yang sudah terkumpul kemudian diolah sehingga menghasilkan suatu output.

1) Analisis Tingkat Kepentingan

Analisis tingkat kepentingan dilakukan bertujuan untuk mengetahui pandangan dari pihak-pihak yang berperan dan terlibat terkait titik masalah pada Dinas Pariwisata. Terdapat 5 indikator nilai yang digunakan untuk mewakili poin dari setiap pertanyaan tingkat kepentingan. Berikut merupakan kelima indikator tingkat kepentingan.

a) Sangat Penting (SP) merupakan indikator nilai yang dipilih responden untuk pertanyaan yang dianggap sangat penting, prioritas utama dan memerlukan evaluasi lebih lanjut melalui capabily level. (Nilai bobot: 5)

b) Penting (P) merupakan indikator nilai yang dipilih responden untuk pertanyaan yang dianggap penting untuk dilakukan penilaian kapabilitas tetapi tidak menjadi prioritas utama. (Nilai bobot: 4)

c) Cukup Penting (CP) merupakan indikator nilai yang dipilih responden untuk pertanyaan cukup penting namun bukan keharusan untuk melakukan penilaian lebih jauh. (Nilai bobot: 3 )

d) Tidak penting (TP) merupakan indikator nilai yang dipilih responden untuk pertanyaan yang dirasa tidak terlalu penting untuk dilakukan penilaian tingkat kapabilitas lebih lanjut. (Nilai bobot: 2)

e) Sangat Tidak Penting (STP) merupakan indikator nilai yang dipilih responden untuk pertanyaan yang dianggap sangat tidak penting dan tidak perlu dilakukan tindakan penilaian tingkat kapabilitas. (Nilai bobot: 1)

2) Analisis Capability Level

Analisis capability level merupakan tahapan proses untuk mengetahui capability level suatu organisasi. Proses analisis capability level adalah proses yang dilakukan setelah melalui tahapan analisis kepentingan sehingga memfokuskan proses yang dianggap penting sesuai hasil kuesioner kepentingan. Berikut merupakan tingkatan capability model.

\section{TABEL 7. RESPONDEN KUESIONER TINGKAT KEMATANGAN}

\begin{tabular}{|c|l|}
\hline Level & \multicolumn{1}{|c|}{ Nama Tigkatan } \\
\hline 0 & $\begin{array}{l}\text { Incomplete Process - Proses tidak diimplementasikan } \\
\text { atau gagal mencapai tujuan. Tingkatan ini hanya ada } \\
\text { sedikit bukti atau bahkan tidak ada bukti adanya } \\
\text { pencapaian sistematik dari tujuan proses tersebut. }\end{array}$ \\
\hline 1 & $\begin{array}{l}\text { Performed Process - Proses yang diimplementasikan } \\
\text { telah berhasil dilaksanakan atau mencapai tujuan }\end{array}$ \\
\hline 2 & $\begin{array}{l}\text { Managed Process - Proses yang telah dilaksanakan dan } \\
\text { diimplementasikan telah dikelola dengan teratur } \\
\text { (direncanakan, dipantau, dan disesuaikan) serta output } \\
\text { dari proses yang dihasilkan telah ditetapkan, dikendalikan } \\
\text { dan dijaga dengan baik. }\end{array}$ \\
\hline
\end{tabular}




\begin{tabular}{|c|l|}
\hline 3 & $\begin{array}{l}\text { Established Process - Proses telah diimplementasikan } \\
\text { menggunakan standar prosedur yang telah ditetapkan } \\
\text { yang mampu mencapai hasil yang diharapkan. }\end{array}$ \\
\hline 4 & $\begin{array}{l}\text { Predictable Process - Proses dijalankan menggunakan } \\
\text { standar prosedur yang ditetapkan serta proses dan } \\
\text { hasilnya dapat diperkirakan dalam batasan waktu yang } \\
\text { ditentukan. }\end{array}$ \\
\hline 5 & $\begin{array}{l}\text { Optimising Process - Kinerja proses terus ditigkatkan } \\
\text { secara berkelanjutan serta melakukan perbaikan dan } \\
\text { inovasi yang berkelanjutan untuk mengkatkan } \\
\text { kemampuan }\end{array}$ \\
\hline
\end{tabular}

Tabel 7 merupakan uraian dari tingkat kapabilitas pada COBIT 5 yang terdiri dari level 0 hingga level 5. Tingkatan setiap level pada capability mewakili sejauh mana proses TI sudah dijalankan dalam organisasi

\section{3) Rating Skala Penilaian Capability Proses TI}

Penilaian dari kuesioner capability dilakukan dengan memberikan nilai persen setiap level berdasarkan sejauh mana proses yang sedang berjalan. Berikut merupakan penjabaran dari penilaian capability proses.

\section{TABEL 8. RESPONDEN KUESIONER TINGKAT KEMATANGAN}

\begin{tabular}{|l|l|}
\hline \multicolumn{1}{|c|}{ Status } & Nilai \\
\hline $\begin{array}{l}\text { Not Achieved (Belum tercapai) } \\
\text { Tahapan ini proses belum diimplementasikan } \\
\text { dan belum mencapai tujuan }\end{array}$ & 0 - \\
\hline $\begin{array}{l}\text { Partially Achieved (Tercapai sebagian) } \\
\text { Tahapan ini telah dilakukan pendekatan secara } \\
\text { sistematis untuk melakukan implementasi proses } \\
\text { namun masih terdapat beberapa bagian dari } \\
\text { proses yang masih belum tercapai. }\end{array}$ & $50 \%$ \\
\hline $\begin{array}{l}\text { Largely Achieved (Sebagaian besar sudah } \\
\text { tercapai) }\end{array}$ & \\
$\begin{array}{l}\text { Tahapan ini telah dilakukan pendekatan secara } \\
\text { sistematis terhadap proses implementasinya telah } \\
\text { dilaksakan tetapi belum sempurna }\end{array}$ & $85 \%$ \\
\hline $\begin{array}{l}\text { Fully Achieve (Tercapai sepenuhnya) } \\
\text { Tahapan ini proses telah diimplementasi } \\
\text { sepenuhnya dan mencapai tujuan. }\end{array}$ & $>85-$ \\
\hline
\end{tabular}

\section{G. Penentuan GAP}

Penentuan nilai GAP atau tingkat kesenjangan adalah tahapan dimana nilai capability yang telah diperoleh pada tahapan sebelumnya dikomparasi dengan nilai ekspektasi yang diinginkan oleh pihak Dinas Pariwisata Kabupaten X. Selisih antara nilai capability dengan nilai ekpektasi menjadi nilai kesenjangan yang menjadi hasil dari penentuan nilai GAP.

\section{HASIL DAN PEMBAHASAN}

Hasil dan Pembahasan merupakan uraian secara rinci dari hasil penelitian yang dilakukan pada Dinas Pariwisata Kabupaten X. Penelitian yang dilakukan dimulai dari pemilihan domain proses TI sampai dengan pemberian saran perbaikan instansi terkait.

\section{A. Indikator Kinerja}

Indikator kerja merupakan ruang lingkup evaluasi yang diangkat dalam penelitian audit. Indikator kerja merupakan turunan dari visi dan misi suatu organisasi. Visi dan misi merupakan pernyataan yang mendefinisikan sesuatu yang ingin dicapai dalam suatu perusahaan secara luas dengan jangka waktu yang panjang. Berikut indikator kerja yang termuat pada Dinas Pariwisata Kabupaten X.

1) Persentase administrasi perkantoran yang mendukung kelancaran tugas dan fungsi PD

2) Persentase sarana dan prasarana aparatur dalam kondisi baik dan mendukung tugas dan fungsi perangkat daerah

3) Persentase serapan anggaran sesuai target

4) Jumlah DTW yang dikunjungi wisatawan

5) Jumlah Desa Wisata/Agro Wisata yang berkembang

\section{B. Identifikasi Tujuan Bisnis}

Identifikasi tujuan bisnis menurut framework COBIT 5 memiliki 4 perspektif yaitu perspektif keuangan, pelanggan, internal serta pembelejaran dan pertumbuhan yang berjumlah 17 tujuan bisnis. Proses identifikasi tujuan bisnis dilakukan dengan memetakan indikator kinerja terhadap tujuan bisnis menurut framework COBIT 5. Hasil pemetaan tujuan bisnis dapat dilihat pada Tabel 3 .

\section{TABEL 9. HASIL PEMETAAN TUJUAN BISNIS}

\begin{tabular}{|c|l|c|l|}
\hline \multirow{2}{*}{ No } & \multicolumn{1}{|c|}{ Indikator Kerja Program } & \multicolumn{2}{|c|}{ Tujuan Bisnis } \\
\cline { 2 - 4 } & $\begin{array}{l}\text { Persentase administrasi perkantoran } \\
\text { yang mendukung kelancaran tugas } \\
\text { dan fungsi PD }\end{array}$ & 11 & $\begin{array}{l}\text { Optimisasi fungsi } \\
\text { bisnis proses }\end{array}$ \\
\hline 2 & $\begin{array}{l}\text { Persentase sarana dan prasarana } \\
\text { aparatur dalam kondisi baik dan } \\
\text { mendukung tugas dan fungsi PD }\end{array}$ & 11 & $\begin{array}{l}\text { Optimisasi fungsi } \\
\text { bisnis proses }\end{array}$ \\
\hline 3 & $\begin{array}{l}\text { Persentase serapan anggaran sesuai } \\
\text { target }\end{array}$ & 12 & $\begin{array}{l}\text { Optimisasi biaya } \\
\text { bisnis proses }\end{array}$ \\
\hline 4 & $\begin{array}{l}\text { Jumlah DTW yang dikunjungi } \\
\text { wisatawan }\end{array}$ & 7 & $\begin{array}{l}\text { Ketersediaan } \\
\text { layanan bisnis yang } \\
\text { berkelanjutan }\end{array}$ \\
\hline 5 & $\begin{array}{l}\text { Jumlah Desa Wisata/Agro Wisata } \\
\text { yang berkembang }\end{array}$ & 17 & $\begin{array}{l}\text { Produk dan inovasi } \\
\text { bisnis berdasarkan } \\
\text { budaya }\end{array}$ \\
\hline
\end{tabular}

Tabel 9 merupakan hasil pemetaan antara indikator kinerja yang diperoleh dengan tujuan bisnis berdasarkan COBIT 5. Indikator kinerja yang dipetakan dengan tujuan bisnis dalam framework COBIT 5, hasil dari pemetaan indikator kerja dengan tujuan bisnis menghasilkan 4 tujuan bisnis.

\section{Identifikasi Tujuan TI}

Identifikasi Tujuan TI menurut framework COBIT 5 memiliki 4 perspektif yaitu perspektif keuangan, pelanggan, internal serta pembelejaran dan pertumbuhan yang berjumlah 17 tujuan TI. Hasil pemetaan tujuan bisnis dengan tujuan TI berdasarkan framework COBIT 5 seperti pada Tabel 4. 
TABEL 10. HASIL PEMETAAN TUJUAN TI

\begin{tabular}{|c|c|c|c|}
\hline No & Tujuan Bisnis & No & Tujuan TI \\
\hline \multirow[t]{3}{*}{7} & \multirow{3}{*}{$\begin{array}{l}\text { Ketersediaan } \\
\text { layanan bisnis } \\
\text { yang } \\
\text { berkelanjutan }\end{array}$} & 4 & $\begin{array}{l}\text { Menangani masalah TI yang terkait } \\
\text { resiko bisnis }\end{array}$ \\
\hline & & 10 & $\begin{array}{l}\text { Keamanan informasi, } \\
\text { infrastruktur dan aplikasi }\end{array}$ \\
\hline & & 14 & $\begin{array}{l}\text { Ketersediaan informasi yang dapat } \\
\text { dipercaya dan bermanfaat bagi } \\
\text { pengambilan keputusan }\end{array}$ \\
\hline \multirow[t]{3}{*}{11} & \multirow{3}{*}{$\begin{array}{l}\text { Optimisasi } \\
\text { fungsi bisnis } \\
\text { proses }\end{array}$} & 1 & Penyelarasan TI dengan strategi bisnis \\
\hline & & 7 & $\begin{array}{l}\text { Pengiriman layanan TI yang sesuai } \\
\text { dengan kebutuhan bisnis }\end{array}$ \\
\hline & & 8 & $\begin{array}{l}\text { Penggunaan aplikasi, informasi, dan } \\
\text { solusi teknologi yang memadai }\end{array}$ \\
\hline \multirow[t]{3}{*}{12} & \multirow[t]{3}{*}{$\begin{array}{l}\text { Optimisasi } \\
\text { biaya bisnis } \\
\text { proses }\end{array}$} & 5 & $\begin{array}{l}\text { Menyadari adanya manfaat dari } \\
\text { diberdayakannya investasi pada bidang } \\
\text { TI dan layanan portofolio }\end{array}$ \\
\hline & & 6 & $\begin{array}{l}\text { Transparansi pada biaya, manfaat, serta } \\
\text { resiko TI }\end{array}$ \\
\hline & & 11 & $\begin{array}{l}\text { Optimisasi aset, sumberdaya serta } \\
\text { kemampuan TI }\end{array}$ \\
\hline \multirow[t]{2}{*}{17} & \multirow{2}{*}{$\begin{array}{l}\text { Produk dan } \\
\text { inovasi bisnis } \\
\text { berdasarkan } \\
\text { budaya }\end{array}$} & 9 & Ketangkasan TI \\
\hline & & 17 & $\begin{array}{l}\text { Pengetahuan, keahlian, dan inisiatif } \\
\text { untuk inovasi bisnis }\end{array}$ \\
\hline
\end{tabular}

\section{Identifikasi Proses TI}

Identifikasi Proses TI merupakan tahap terakhir dalam pemilihan Proses TI. Pemetaan dengan proses TI terkait tujuan TI terdiri dari lima domain, yaitu EDM (Evaluate, Direct, and Monitor), APO (Align, Plan, and Organize), BAI (Build, Acquire, and Implement), DSS (Deliver, Service, and Support), MEA (Monitor, Evaluate, and Assess).

TABEL 11. IDENTIFIKASI PROSES TI

\begin{tabular}{|c|c|c|c|c|c|c|}
\hline \multirow{2}{*}{$\begin{array}{l}\mathbf{N} \\
\mathbf{O}\end{array}$} & \multirow{2}{*}{ Tujuan TI } & \multicolumn{5}{|c|}{ Proses TI } \\
\hline & & $\begin{array}{c}\text { ED } \\
\text { M }\end{array}$ & APO & $\begin{array}{c}\text { B } \\
\text { AI }\end{array}$ & DSS & $\begin{array}{r}\mathbf{M} \\
\mathbf{E A}\end{array}$ \\
\hline 1 & $\begin{array}{l}\text { Penyelarasan TI dengan } \\
\text { strategi bisnis }\end{array}$ & 1,2 & $\begin{array}{l}1,2,3 \\
, 5,7 \\
8\end{array}$ & $\begin{array}{l}1, \\
2\end{array}$ & & \\
\hline 4 & $\begin{array}{l}\text { Menangani masalah TI } \\
\text { yang terkait resiko bisnis }\end{array}$ & & $\begin{array}{l}10,1 \\
1,12\end{array}$ & 1,6 & $\begin{array}{l}1,2,3 \\
4,5 \\
6\end{array}$ & $\begin{array}{c}1,2, \\
3\end{array}$ \\
\hline 5 & $\begin{array}{l}\text { Menyadari adanya manfaat } \\
\text { dari diberdayakannya } \\
\text { investasi pada bidang TI } \\
\text { dan layanan portofolio }\end{array}$ & & $\begin{array}{c}4,5,6 \\
, 11\end{array}$ & 1 & & \\
\hline 6 & $\begin{array}{l}\text { Transparansi pada biaya, } \\
\text { manfaat, serta resiko TI }\end{array}$ & 5 & $\begin{array}{c}6,12 \\
13 \\
\end{array}$ & 9 & & \\
\hline 7 & $\begin{array}{l}\text { Pengiriman layanan TI } \\
\text { yang sesuai dengan } \\
\text { kebutuhan bisnis }\end{array}$ & 5 & $\begin{array}{c}2,8,9 \\
10,1 \\
1\end{array}$ & $\begin{array}{c}2,3 \\
, 4 \\
6\end{array}$ & $\begin{array}{l}1,2,3 \\
, 4,6\end{array}$ & 1 \\
\hline 8 & $\begin{array}{lr}\text { Penggunaan } & \text { aplikasi, } \\
\text { informasi, dan } & \text { solusi } \\
\text { teknologi yang memadai }\end{array}$ & & 4 & 5,7 & & \\
\hline 9 & Ketangkasan TI & 4 & $\begin{array}{c}1,2,3 \\
, 9\end{array}$ & 8 & & \\
\hline $\begin{array}{l}1 \\
0\end{array}$ & $\begin{array}{lr}\text { Keamanan } & \text { informasi, } \\
\text { pemrosesan } & \text { infrastruktur }\end{array}$ & & $\begin{array}{c}12,1 \\
3\end{array}$ & 6 & 5 & \\
\hline
\end{tabular}

\begin{tabular}{|r|l|c|c|c|c|c|}
\hline & dan aplikasi aset, & & & & & \\
\hline 1 & $\begin{array}{l}\text { Optimisasi serta } \\
\text { sumberdaya } \\
\text { kemampuan TI }\end{array}$ & $\begin{array}{c}1,3,4 \\
, 7\end{array}$ & $\begin{array}{c}4,9 \\
, 10\end{array}$ & 3 & 1 \\
\hline & $\begin{array}{l}\text { Ketersediaan informasi } \\
\text { yang dapat dipercaya dan } \\
4\end{array}$ & $\begin{array}{l}\text { bermanfaatragi } \\
\text { pengambilan keputusan }\end{array}$ & 9,13 & $\begin{array}{c}4,1 \\
0\end{array}$ & 3,4 & \\
\hline 1 & $\begin{array}{l}\text { Pengetahuan, keahlian, dan } \\
\text { inisiatif untuk inovasi bisnis }\end{array}$ & & $\begin{array}{c}1,4,7 \\
, 8\end{array}$ & 5,8 & & \\
\hline
\end{tabular}

Tabel 11 merupakan hasil pemetaan tujuan TI dengan proses TI. Proses TI terdiri dari 5 domain yaitu EDM (Evaluate, Direct, Monitor), APO (Align, Plan, Organise), BAI (Build, Acquire, Implement), DSS (Deliver, Service, Support) dan MEA (Monitor, Evaluate, Assess). Berikut adalah tabel rangkuman domain dan proses TI yang yang dipersempit setelah melakukan pemetaan dengan indikator kerja.

\section{TABEL 12. PROSES TI PADA DINAS PARIWISATA KABUPATEN X}

\begin{tabular}{|c|l|l|l|}
\hline No & Domain & \multicolumn{1}{|c|}{ Proses TI } & \multicolumn{1}{c|}{ Indikator Kerja } \\
\hline 1 & EDM 02 & $\begin{array}{l}\text { Ensure benefit delivery } \\
\text { (Memastikan } \\
\text { penyampaian yang } \\
\text { bermanfaat) }\end{array}$ & $\begin{array}{l}\text { Persentase administrasi } \\
\text { perkantoran yang } \\
\text { mendukung kelancaran } \\
\text { tugas dan fungsi PD }\end{array}$ \\
\hline 2 & BAI 04 & $\begin{array}{l}\text { Manage availability } \\
\text { and capacity } \\
\text { (Mengelola } \\
\text { ketersediaan } \\
\text { dan kapasitas) }\end{array}$ & $\begin{array}{l}\text { Persentase sarana dan } \\
\text { prasarana aparatur } \\
\text { dalam kondisi baik dan } \\
\text { mendukung tugas dan } \\
\text { fungsi PD }\end{array}$ \\
\hline 3 & APO 06 & $\begin{array}{l}\text { Manage budget and } \\
\text { cost (Mengelola } \\
\text { anggaran dan biaya) }\end{array}$ & $\begin{array}{l}\text { Persentase } \\
\text { anggaran sesuai target }\end{array}$ \\
\hline 4 & DSS 02 & $\begin{array}{l}\text { Manage service request } \\
\text { and incidents } \\
\text { (Mengelola permintaan } \\
\text { layanan serta insiden) }\end{array}$ & $\begin{array}{l}\text { Jumlah DTW yang } \\
\text { dikunjungi wisatawan }\end{array}$ \\
\hline 5 & APO 04 & $\begin{array}{l}\text { Manage innovation } \\
\text { (Mengelola inovasi) }\end{array}$ & $\begin{array}{l}\text { Jumlah Wisata/Agro Wisata } \\
\text { yang berkembang }\end{array}$ \\
\hline
\end{tabular}

Tabel 12 merupakan uraian dari pemetaan ulang proses TI dengan indikator kerja pada Dinas Pariwisata Kabupaten $\mathrm{X}$. Proses pemetaan dilakukan bertujuan untuk memfokuskan dan menghasilkan proses TI yang berkorelasi dengan indikator kerja.

\section{E. Penentuan RACI Chart}

Pemetaan RACI chart bertujuan agar penentuan responden dari kuesioner tepat sasaran sesuai dengan tugas dan wewenang pihak yang terlibat, sehingga menghasilkan hasil yang akurat. Responden yaitu pihak-pihak yang berada pada top dan middle management di Dinas yang memiliki keterkaitan dengan proses bisnis berdasarkan program kerja. Berikut merupakan tabel dasar pelaksana tugas untuk menentukan entitas RACI chart pada Dinas Pariwisata Kabupaten X.

\section{TABEL 13. RACI CHART BIDANG KEPEGAWAIAN} DAN KESEKRETARIATAN 


\begin{tabular}{|c|c|c|c|c|c|c|c|c|c|}
\hline \multirow{3}{*}{ Activities } & \multicolumn{9}{|c|}{ Entity } \\
\hline & 1 & 2 & 3 & 4 & 5 & 6 & 7 & & 9 \\
\hline & \multicolumn{9}{|c|}{ Component } \\
\hline $\begin{array}{l}\text { Memastikan terpenuhinya kebutuhan } \\
\text { administrasi perkantoran yang } \\
\text { mendukung kelancaran tugas dan } \\
\text { fungsi perangkat daerah pada Dinas } \\
\text { Pariwisata Kabupaten X. }\end{array}$ & A & I & $\mathrm{R}$ & C & $\mathrm{C}$ & $\mathrm{R}$ & $\mathrm{R}$ & $\mathrm{R}$ & $\mathrm{R}$ \\
\hline $\begin{array}{l}\text { Memastikan terpenuhinya sarana dan } \\
\text { prasana aparatur dalam kondisi baik } \\
\text { dan mendukung tugas dan fungsi PD di } \\
\text { Dinas Pariwisata Kabupaten X. }\end{array}$ & $\mathrm{A}$ & I & $\mathrm{C}$ & $\mathrm{C}$ & $\mathrm{R}$ & $\mathrm{R}$ & $\mathrm{R}$ & $\mathrm{R}$ & $\mathrm{R}$ \\
\hline $\begin{array}{l}\text { Memastikan capaian kinerja dan } \\
\text { serapan anggaran sesuai target. }\end{array}$ & $\mathrm{A}$ & $\mathrm{C}$ & $\mathrm{C}$ & I & $\mathrm{R}$ & $\mathrm{R}$ & $\mathrm{R}$ & $\mathrm{R}$ & $\mathrm{R}$ \\
\hline
\end{tabular}

Tabel 13 merupakan penentuan bagan RACI yang telah disesuaikan dengan proses pemahaman tingkat kepentingan berdasarkan referensi proses TI hasil pemetaan tujuan bisnis dan sasaran TI. Komponen Bagan RACI chart terdiri dari Responsible (R) yaitu orang yang melakukan kegiatan, Accountable (A) yaitu orang yang akhirnya bertanggung jawab, Consult (C) yaitu Orang yang diperlukan umpan balik atau sarannya dan berkontribusi akan kegiatan tersebut, dan Inform (I) yaitu Orang yang perlu tahu hasil dari suatu keputusan atau tindakan. Entitas bagan RACI terdiri dari Kepala Dinas (1), Sekretaris Dinas (2), Kasub Bagian Umum dan Kepegawaian (3), Kasub Bagian Keuangan (4), Kasub Bagian Perencanaan dan Pelaporan (5), Kepala Bidang Pengendalian Usaha Pariwisata (6), Kepala Bidang Obyek dan Daya Tarik Wisata (7), Kepala Bidang Promosi dan Pemasaran Pariwisata (8), Kepala Bidang Sumber Daya Pariwisata (9).

\section{$F$. Penentuan Tingkat Kepentingan}

Penentuan tingkat kepentingan merupakan tahapan proses audit dengan melakukan penyebaran kuesioner kepada responden yang memiliki tanggung jawab terhadap indikator kerja yang berjalan pada Dinas. Penentuan tingkat kepentingan, ditentukan berdasarkan indikator kerja yang diangkat menjadi cangkupan evaluasi dari proses audit yang dinilai oleh responden berdasarkan lima tingkat kepentingan.

\section{TABEL 14. KUESIONER TINGKAT KEPENTINGAN}

\begin{tabular}{|c|c|c|c|c|c|c|c|}
\hline $\begin{array}{l}\mathbf{N} \\
\mathbf{0}\end{array}$ & Pernyataan & $\begin{array}{c}\text { ST } \\
\mathbf{P} \\
(1)\end{array}$ & $\begin{array}{l}\mathbf{T} \\
\mathbf{P} \\
(2 \\
)\end{array}$ & $\begin{array}{l}\mathbf{C} \\
\mathbf{P} \\
(3 \\
)\end{array}$ & $\begin{array}{l}\mathbf{P} \\
(4 \\
)\end{array}$ & $\begin{array}{l}\mathbf{S} \\
\mathbf{P} \\
(5 \\
)\end{array}$ & $\begin{array}{c}\text { Tota } \\
1 \\
\left(\mathbf{N}^{*}\right. \\
\text { B) }\end{array}$ \\
\hline 1 & $\begin{array}{l}\text { Terpenuhinya kebutuhan } \\
\text { administrasi perkantoran } \\
\text { yang mendukung } \\
\text { kelancaran tugas dan } \\
\text { fungsi perangkat daerah }\end{array}$ & & & & 3 & 6 & 42 \\
\hline 2 & $\begin{array}{l}\text { Terpenuhinya sarana dan } \\
\text { prasana aparatur dalam } \\
\text { kondisi baik dan } \\
\text { mendukung tugas dan } \\
\text { fungsi Perangkat Daerah }\end{array}$ & & & & 3 & 6 & 42 \\
\hline 3 & $\begin{array}{l}\text { Terpenuhinya capaian } \\
\text { kinerja dan serapan } \\
\text { anggaran sesuai dengan } \\
\text { target yang ditentukan }\end{array}$ & & & & 2 & 7 & 43 \\
\hline
\end{tabular}

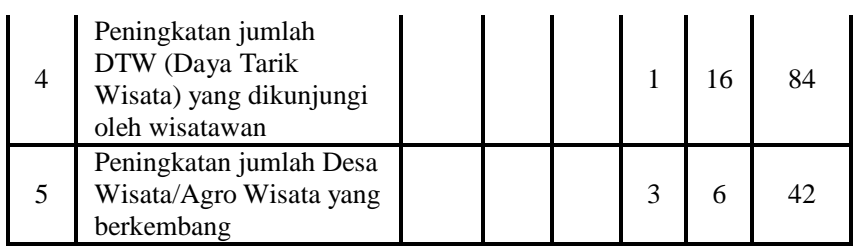

Tabel 14 merupakan Kuesioner tingkat kepentingan yang memiliki lima nilai bobot yaitu Sangat Tidak Penting (STP) dengan nilai bobot 1 , Tidak Penting (TP) dengan nilai bobot 2, Cukup Penting (CP) dengan bobot nilai 3, Penting (P) dengan nilai bobot 4, dan Sangat Penting (SP) dengan bobot nilai 5. Hasil perhitungan domain diperoleh dengan melakukan penyelarasan dari hasil pemetaan indikator kinerja dengan tujuan bisnis, tujuan TI dan proses TI serta hasil dari kuesioner tingkat kepentingan, sehingga hasilnya dapat diurutkan berdasarkan nilai tertinggi. Berikut merupakan 5 domain yang telah diurutkan

\section{$G$. Penentuan Tingkat Kematangan}

Kuesioner tingkat kematangan berisi poin pertanyaan yang digunakan dalam pernyataan kuesioner, deskripsi area proses TI, dan pertanyaan yang perlu dijawab oleh responden. Kuesioner tingkat kematangan dirancang dengan mengacu pada dokumen PAM Using COBIT 5 Toolkit Self Assessment Templates [17]. Hasil kuesioner kapabilitas digunakan untuk mengetahui tingkat capability process yang diaudit.

\section{TABEL 15 HASIL KUESIONER TINGKAT KEMATANGAN PADA DOAMIN EDM02}

\begin{tabular}{|c|c|c|c|c|c|c|c|c|c|c|}
\hline $\begin{array}{l}\mathbf{N} \\
\mathbf{0}\end{array}$ & $\begin{array}{c}\text { Respond } \\
\text { en }\end{array}$ & $\begin{array}{l}\text { Lv } \\
1.1\end{array}$ & $\begin{array}{l}\text { Lv } \\
2.1\end{array}$ & $\begin{array}{l}\mathbf{L} \\
\mathbf{v} \\
2 . \\
2\end{array}$ & $\begin{array}{l}\text { Lv } \\
3.1\end{array}$ & $\begin{array}{l}\text { Lv } \\
3.2\end{array}$ & $\begin{array}{l}\text { Lv } \\
4.1\end{array}$ & $\begin{array}{l}\text { Lv } \\
4.2\end{array}$ & $\begin{array}{l}\text { L } \\
\text { v } \\
5 . \\
1\end{array}$ & $\begin{array}{l}\text { Lv } \\
5.2\end{array}$ \\
\hline 1 & $\begin{array}{l}\text { Kasub } \\
\text { Bagian } \\
\text { Umum } \\
\text { dan } \\
\text { Kepegaw } \\
\text { aian }\end{array}$ & 83 & 85 & $\begin{array}{l}8 \\
5\end{array}$ & 85 & 83 & 85 & 85 & $\begin{array}{l}8 \\
5\end{array}$ & 85 \\
\hline 2 & $\begin{array}{l}\text { Kepala } \\
\text { Bidang } \\
\text { Pengenda } \\
\text { lian } \\
\text { Usaha } \\
\text { Pariwisat } \\
\text { a }\end{array}$ & 70 & 80 & $\begin{array}{l}8 \\
3, \\
7 \\
5\end{array}$ & 85 & $\begin{array}{c}85 \\
8\end{array}$ & $\begin{array}{c}85 \\
8\end{array}$ & 84 & $\begin{array}{l}7 \\
9\end{array}$ & $\begin{array}{c}71, \\
6\end{array}$ \\
\hline 3 & $\begin{array}{l}\text { Kepala } \\
\text { Bidang } \\
\text { Obyek } \\
\text { dan Daya } \\
\text { Tarik } \\
\text { Wisata } \\
\end{array}$ & $\begin{array}{c}75 \\
6\end{array}$ & 80 & $\begin{array}{l}8 \\
0\end{array}$ & 82 & 82 & $\begin{array}{c}80, \\
8\end{array}$ & 79 & $\begin{array}{l}7 \\
5\end{array}$ & $\begin{array}{c}76 \\
6\end{array}$ \\
\hline 4 & $\begin{array}{l}\text { Kepala } \\
\text { Bidang } \\
\text { Promosi } \\
\text { dan } \\
\text { Pemasara } \\
\text { n } \\
\text { Pariwisat } \\
\text { a }\end{array}$ & 75 & $\begin{array}{c}77, \\
5\end{array}$ & $\begin{array}{l}8 \\
5\end{array}$ & 80 & $\begin{array}{c}81, \\
6\end{array}$ & 80 & 78 & $\begin{array}{l}8 \\
1\end{array}$ & $\begin{array}{c}78, \\
3\end{array}$ \\
\hline 5 & $\begin{array}{l}\text { Kepala } \\
\text { Bidang }\end{array}$ & 80 & 85 & $\begin{array}{l}8 \\
0\end{array}$ & 75 & 80 & 75 & 70 & $\begin{array}{l}8 \\
0\end{array}$ & 85 \\
\hline
\end{tabular}




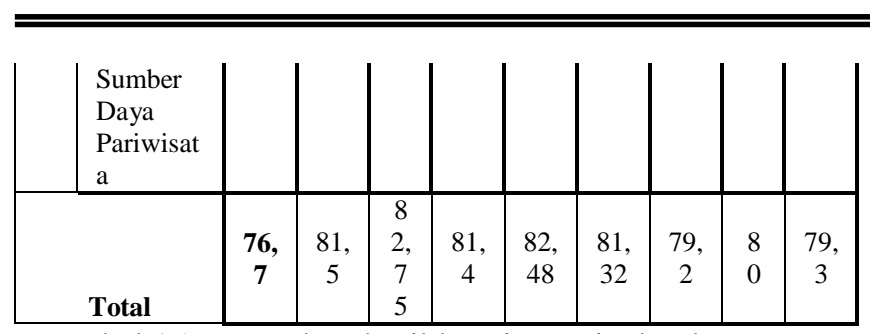

Tabel 15 merupakan hasil kuesioner tingkat kematangan pada doamin EDM02. Penilaian tersebut dilakukan oleh lima responden. Tabel diatas menunjukan proses pada EDM02 berada pada level 1, karena hasil nilai rata-rata yang diperoleh dari 5 responden adalah sebesar 76,7 pada level 1 . Hasil berada pada level 1 karena nilai level 1 masih belum mencapi rata-rata 85, sehingga belum memenuhi standar untuk melanjutkan ke level selanjutnya. Rata-rata kedua tahapan harus diatas 85 untuk dapat melanjutkan ke level selanjutnya. Hasil penilaian pada tabel diatas mengacu berdasarkan sumber COBIT 5 Self Assesment Templates.

\section{H. GAP (Kesenjangan)}

Tingkat GAP atau kesenjangan dari tingkat kapabilitas merupakan selisih antara kapabilitas yang diharapkan (Expected capability) dengan kapabilitas saat ini (Curent Capability). Kesenjangan antara empat proses TI yang diaudit ditunjukkan pada Tabel 16 di bawah ini

TABEL 16. GAP CAPABILITY LEVEL

\begin{tabular}{|c|c|c|c|}
\hline Domain & $\begin{array}{c}\text { Current } \\
\text { Capability }\end{array}$ & $\begin{array}{c}\text { Expected } \\
\text { Capability }\end{array}$ & GAP \\
\hline DSS02 & 1 & 4 & 3 \\
\hline APO06 & 1 & 4 & 3 \\
\hline EDM02 & 1 & 4 & 3 \\
\hline BAI04 & 1 & 4 & 3 \\
\hline APO04 & 1 & 4 & 3 \\
\hline
\end{tabular}

Tabel 16 merupakan tingkat kematangan yang didapatkan berdasarkan hasil kuesioner kematangan dan melakukan wawancara mengenai target capability pada Dinas Pariwisata Kabupaten X. Curent Capability merupakan nilai kematangan saat ini yang dinilai berdasarkan kuesioner kematangan. Expected capability merupakan target yang diharapkan. Proses pencapaian tujuan dan GAP adalah nilai kesenjangan yang merupakan selisih dari current capability dan expected capability. Berikut merupakan grafik spider chart GAP capability level pada Dinas Pariwisata Kabupaten $\mathrm{X}$.

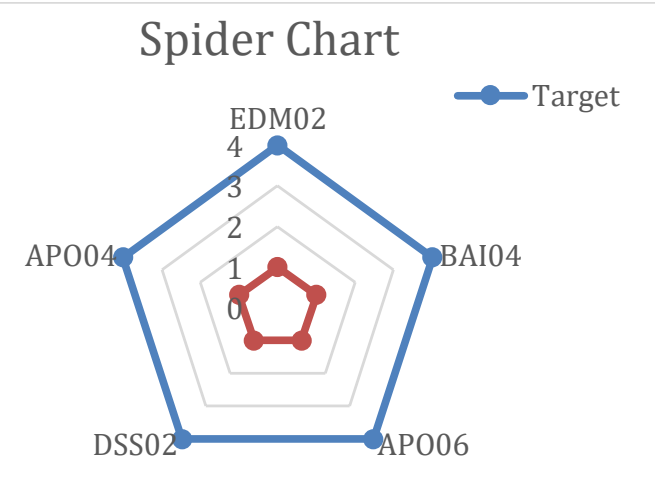

\section{Rekomendasi Perbaikan}

Gambar. 4 Spider Chart

Rekomendasi perbaikan tata kelola teknologi informasi diarahkan menuju tingkat kematangan yang diharapkan yaitu tingkat kematangan 4-Predictable , dari tingkat yang lebih rendah menuju satu tingkat kematangan di atasnya secara urut. Kesenjangan dari capability level proses TI dapat diatasi dengan menggunakan pedoman dari COBIT 5, sehingga langkah selanjutnya menangani perbaikan terhadap layanan surat keterangan asal untuk menuju capability level yang diaharapkan. Contoh kajian Rekomendasi dan perbaikan domain proses terdapat pada Tabel 17.

\section{TABEL 17. REKOMENDASI PERBAIKAN}

\begin{tabular}{|c|c|c|}
\hline No & Domain & Rekomendasi Perbaikan \\
\hline 1 & DSS02 & $\begin{array}{l}\text { Kepala Seksi Daya Tarik Wisata disarankan untuk } \\
\text { mencatat dan mengklasifikasikan semua permintaan } \\
\text { dan layanan terkait insiden dengan mengidentifikasi } \\
\text { jenis dan kategori yang ada pada daya tarik wisata agar } \\
\text { dapat ditangani secara efektif. (COBIT } 5 \text { Enabling } \\
\text { Process, DSS02 Record, classify and prioritise } \\
\text { requests and incidents). }\end{array}$ \\
\hline 2 & APO06 & $\begin{array}{l}\text { Kasub Bagian Perencanaan dan Pelaporan disarankan } \\
\text { agar menentukan skema klasifikasi untuk } \\
\text { mengidentifikasi semua elemen biaya terkait TI dan } \\
\text { bagaimana biaya tersebut dialokasikan di seluruh } \\
\text { anggaran dan layanan agar mencapai target yang } \\
\text { diharapkan. (COBIT } 5 \text { Enabling Process, APO06 } \\
\text { Manage finance and accounting). }\end{array}$ \\
\hline 3 & EDM02 & $\begin{array}{l}\text { Kepala Sub Bagian Umum dan Kepegawaian } \\
\text { disarankan } \\
\text { mengkomunikasikan portofolio dan jenis investasi, } \\
\text { kategori, kriteria, dan bobot nilai untuk menentukan } \\
\text { standar administrasi perkantoran pada dinas. (COBIT } \\
5 \text { Enabling Process, EDM02 Evaluate value } \\
\text { optimisation). }\end{array}$ \\
\hline 4 & BAI04 & $\begin{array}{l}\text { Kasub Bagian Perencanaan dan Pelaporan disarankan } \\
\text { mengidentifikasi solusi atau layanan yang penting } \\
\text { dalam proses manajemen ketersediaan dan kapasitas } \\
\text { sarana dan prasarana perkantoran. (COBIT } 5 \text { Enabling } \\
\text { Process, BAI04 Assess business impact). }\end{array}$ \\
\hline 5 & $\mathrm{APO} 04$ & $\begin{array}{l}\text { Kepala Seksi Daya Tarik Wisata disarankan untuk } \\
\text { melakukan analisa terkait minat dan potensi yang } \\
\text { dimiliki oleh desa wisata/ agro wisata untuk } \\
\text { mengadopsi teknologi yang paling oportunistik yang } \\
\text { dapat membatu meningkatkan daya tarik wisatawan } \\
\text { untuk berwisata ke desa wisata/ agro wisata. } 03 \\
\text { (COBIT } 5 \text { Enabling Process, APO04 Monitor and } \\
\text { scan the technology environment). }\end{array}$ \\
\hline
\end{tabular}




\section{KESIMPULAN}

Hasil penelitian yang telah dilakukan mengenai audit tata kelola teknologi informasi pada dinas pariwisata kabupaten $\mathrm{X}$ pada domain EDM02, BAI04, APO06, DSS02 dan APO04 secara keseluruhan berada pada level 1 (Performed Process) dengan expected capability 4 sehingga terdapat GAP capability 3. Hal tersebut berarti bahwa secara keseluruhan proses Tata Kelola TI yang diimplementasikan telah berhasil dilaksanakan atau mencapai tujuan, akan tetapi belum secara konsisten. Maka dari itu instansi masih perlu melakukan pembenahan pada beberapa proses agar dapat mencapai level yang diharapakan yaitu level 4 ( Predictable process).

\section{REFERENCES}

A. D. M. Eka Widilianie1, "EVALUASI KINERJA SI PROJECT MANAGEMENT MENGGUNAKAN FRAMEWORK COBIT 5 SUBDOMAIN MEA 01," J. SITECH, Vol 2, No 1, vol. Vol 1, No, pp. 1-6, 2018.

[2] Aldy Maulana Syuhada, "KAJIAN PERBANDINGAN COBIT 5 DENGAN COBIT 2019 SEBAGAI FRAMEWORK AUDIT TATA KELOLA TEKNOLOGI INFORMASI," J. Ilm. Indones. p-ISSN 2541-0849 e-ISSN 2548-1398, vol. 6, no. 1, p. 6, 2021.

[3] M. Adhisyanda Aditya, R. Dicky Mulyana, A. Mulyawan, S. LIKMI Bandung, and S. Mardira Indonesia, "Perbandingan Cobit 2019 Dan Itil V4 Sebagai Panduan Tata Kelola Dan Management It," J. Comput. Bisnis, vol. 13, no. 2, pp. 100-105, 2019.

[4] J. F. Andry, "Audit of IT Governance Based on COBIT 5 Assessments: A Case Study," J. Nas. Teknol. dan Sist. Inf., vol. 2, no. 2, pp. 27-34, 2016, doi: 10.25077/teknosi.v2i2.2016.27-34

[5] H. Nugroho, "Proposed IT Governance at Hospital Based on COBIT 5 Framework," vol. 01, no. 02, pp. 0-2, 2017.

[6] I. Wayan Prasada Bharaditya, I. Made Sukarsa, and P. Wira Buana, "Internal Control Improvement for Creating Good Governance," Int. J. Inf. Eng. Electron. Bus., vol. 9, no. 3, pp. 9-17, 2017, doi: 10.5815/ijieeb.2017.03.02.

[7] Maskur, N. Adolong, and Rusliy Mokodongan, "Implementasi Tata Kelola Teknologi Informasi Menggunakan Framework Cobit 5 di BPMPTSP Bone Bolango Kabupaten Bone Bolango," IT Gov. Implement. Using COBIT 5 Framew. Bone Bolango BPMPTSP, vol. 8, no. 2, pp. 109-126, 2017.

[8] V. Jarsa and K. Christianto, "IT Governance Audit with COBIT 5 Framework on DSS Domain," Kinet. Game Technol. Inf. Syst. Comput. Network, Comput. Electron. Control, vol. 3, no. 4, pp. 279-286, 2018, doi: 10.22219/kinetik.v3i4.665.

[9] J. F. Andry and A. K. Setiawan, "It Governance Evaluation Using Cobit 5 Framework on the National Library," J. Sist. Inf., vol. 15, no. 1, pp. 10-17, 2019, doi: 10.21609/jsi.v15i1.790.

[10] D. F. Kurniawan, "Audit Tata Kelola Teknologi Informasi pada Sistem Informasi Akademik Menggunakan Framework COBIT5 ( Studi Kasus : Amik Master Lampung )," vol. XVII, no. April, pp. 227-232, 2019.

[11] R. P. Kusuma, "Audit Teknologi Informasi Menggunakan Framework Cobit 5 Pada Domain DSS ( Deliver, Service, and Support ) ( Studi Kasus : Konsultan Manajemen Pusat )," vol. 9, no. 1, pp. 97-109, 2019.

[12] R. Y. Sianida, F. N. Afiana, and R. Wahyudi, "IS Governance Evaluation Using COBIT 5 Framework on the Central Statistics Agency of Banyumas District," vol. 1, no. 1, pp. 1-9, 2020.

[13] A. A. Ngurah Aditya Winata, I. Made Sukarsa, and N. Kadek Dwi Rusjayanthi, "Audit Layanan SKA (Surat Keterangan Asal) Untuk Barang Ekspor Menggunakan Framework COBIT 5," J. Ilm. Merpati (Menara Penelit. Akad. Teknol. Informasi), vol. 7, no. 2, p. 103, 2019, doi: 10.24843/jim.2019.v07.i02.p02.

[14] R. E. Putri, "Penilaian Kapabilitas Proses Tata Kelola TI Berdasarkan Proses DSS01 Pada Framework COBIT 5,” vol. 2, no. 1, pp. 41-54, 2016

ISACA, A Business Framework for the Governance and Management of Enterprise IT. 2012.

[16] R. R. Suryono, D. Darwis, and S. I. Gunawan, "Audit Tata Kelola Teknologi Informasi Menggunakan Framework COBIT 5 ( Studi Kasus : Balai Besar Perikanan Budidaya Laut Lampung )," vol. 12, no. 1, pp. 16-22, 2018.

[17] ISACA, COBIT (B) Process Assessment Model (PAM): Using COBIT $\circledR^{8} 5.2013$. 